\title{
WO-scanner econiomie 1995. Basismeting cohort '94
}

\author{
Citation for published version (APA):
}

Ramaekers, G. W. M. (1996). WO-scanner econiomie 1995. Basismeting cohort '94. Researchcentrum voor Onderwijs en Arbeidsmarkt, Faculteit der Economische Wetenschappen. ROA Reports No. 15 https://doi.org/10.26481/umarep.1996015

Document status and date:

Published: 01/01/1996

DOI:

10.26481/umarep.1996015

Document Version:

Publisher's PDF, also known as Version of record

\section{Please check the document version of this publication:}

- A submitted manuscript is the version of the article upon submission and before peer-review. There can be important differences between the submitted version and the official published version of record.

People interested in the research are advised to contact the author for the final version of the publication, or visit the DOI to the publisher's website.

- The final author version and the galley proof are versions of the publication after peer review.

- The final published version features the final layout of the paper including the volume, issue and page numbers.

Link to publication

\footnotetext{
General rights rights.

- You may freely distribute the URL identifying the publication in the public portal. please follow below link for the End User Agreement:

www.umlib.nl/taverne-license

Take down policy

If you believe that this document breaches copyright please contact us at:

repository@maastrichtuniversity.nl

providing details and we will investigate your claim.
}

Copyright and moral rights for the publications made accessible in the public portal are retained by the authors and/or other copyright owners and it is a condition of accessing publications that users recognise and abide by the legal requirements associated with these

- Users may download and print one copy of any publication from the public portal for the purpose of private study or research.

- You may not further distribute the material or use it for any profit-making activity or commercial gain

If the publication is distributed under the terms of Article $25 \mathrm{fa}$ of the Dutch Copyright Act, indicated by the "Taverne" license above, 


\title{
WO-scanner economie 1995 \\ Basismeting cohort '94
}

\author{
ROA-R-1996/15
}

G.W.M. Ramaekers

\section{Researchcentrum voor Onderwijs en Arbeidsmarkt}

Faculteit der Economische Wetenschappen en Bedrijfskunde Universiteit Maastricht

Maastricht, december 1996 
ISBN 90-5321-202-7 


\section{Inhoud}

Bladzijde

Voorwoord

Samenvatting

1 Inleiding

1

1.1 Opzet WO-Scanner Economie

1

1.2 Samenstelling onderzoekspopulatie

2 Intrede op de arbeidsmarkt 9

2.1 Verschuivingen in maatschappelijke positie na afstuderen 9

2.2 Kans op werk

2.3 Verder onderwijs na afstuderen

3 Functiekenmerken 19

3.1 Functieverwerving $\quad 19$

3.2 Werkorganisatie 19

3.3 Functievereisten 24

3.4 Arbeidsvoorwaarden 32

4 Afstemming tussen opleiding en werk 39

4.1 Afstemming tussen opleidingskwalificaties en beroepspraktijk 39

4.2 Behoefte en deelname aan bijscholing $\quad 45$

5 Opleiding achteraf bezien $\quad 49$

5.1 Gewenste bijstelling van het onderwijs $\quad 49$

5.2 Studiekeuze achteraf bezien $\quad 52$

6 Thema: Sexeverschillen bij arbeidsmarktintrede 53

$\begin{array}{ll}\text { Bijlage } 1 \text { Verklarende variabelen } & 57\end{array}$ 



\section{Voorwoord}

In opdracht van het College van Bestuur van de Universiteit Maastricht (UM) verricht het Researchcentrum voor Onderwijs en Arbeidsmarkt (ROA), dat verbonden is aan de Faculteit der Economische Wetenschappen en Bedrijfskunde van de UM, vanaf 1990 jaarlijks onderzoek naar de arbeidsmarktpositie en loopbanen van afgestudeerden - waaronder economen - van de UM. Met ingang van 1994 verricht het $R O A$, in opdracht van de economische faculteiten van de Erasmus Universiteit Rotterdam (EUR) en de Katholieke Universiteit Brabant (KUB), tevens arbeidsmarktonderzoek onder economen die aan de EUR en de KUB zijn afgestudeerd. Vanaf 1996 is dit onderzoek, de WO-Scanner Economie, zelfs uitgebreid tot alle economische faculteiten met uitzondering van de Rijksuniversiteit Groningen. In het onderzoek wordt een uitgebreid beeld verschaft van de arbeidsmarktintrede van de afgestudeerden. Daarnaast wordt een aantal vragen gesteld waarmee de inhoud van het curriculum in het licht van de beroepsuitoefening kan worden geëvalueerd. In dit rapport worden de resultaten gepresenteerd van de enquête die eind 1995 begin 1996 heeft plaatsgevonden. Aan deze enquête, hebben in totaal 1097 economen meegewerkt, namelijk 481 afgestudeerden van de EUR, 425 afgestudeerden van de KUB en 191 afgestudeerden van de UM.

Het ROA voert dit project uit in samenwerking met DESAN Marktonderzoek te Amsterdam. Het ROA heeft bij de uitvoering van het onderzoeksproject de leiding en is verantwoordelijk voor de instrumentontwikkeling, de kwaliteitsbewaking, het databeheer alsmede het thans voorliggende, analytisch gerichte eindrapport. DESAN Marktonderzoek is verantwoordelijk voor de gegevensverzameling, de gegevensverwerking en het maken van de vertrouwelijke, statistische faculteitsrapportages ten behoeve van de deelnemende faculteiten.

De projectleiding, alsmede de uitvoering van de analyses en de verslaglegging van het thans voorliggend eindrapport, is in handen van drs. G.W.M. Ramaekers van het ROA. De vertrouwelijke faculteitsrapportages zijn door drs. ing. K.J. Pagrach van DESAN Marktonderzoek opgesteld, terwijl ing. J.J. Rutjes de werkzaanheden van DESAN Marktonderzoek voor het onderzoeksproject coördineert. Vanuit de EUR wordt het project begeleid door drs. A. Meijdam en drs. N. Twigt, vanuit de KUB door drs. H.G. van Liempd en drs. G.J.M. van den Maagdenberg en vanuit de economische faculteit van de UM door drs. I.M. Wijk.

Uiteraard is dank verschuldigd aan de afgestudeerden die de vragenlijst hebben ingevuld.

Maastricht, december 1996 



\section{Samenvatting}

Eind 1995 - begin 1996 is in het kader van de WO-Scanner Economie voor de tweede keer een arbeidsmarktonderzoek gehouden onder afgestudeerde economen van de EUR, de KUB en de UM. Aangezien de enquête één tot anderhalf jaar na het afstuderen plaatsvindt, heeft het onderzoek betrekking op economen die nog aan het begin staan van hun beroepsloopbaan. Aan de enquête hebben in totaal 1097 economen meegewerkt, hetgeen neerkomt op een respons van $61 \%$.

\section{Samenstelling onderzoekspopulatie}

Van de onderzoekspopulatie is $4 \%$ afgestudeerd in Bestuurlijke Informatiekunde (BIK), $9 \%$ in Econometrie (Ectrie), 10\% in Algemene Economie Economie (AE), 66\% in Bedrijfseconomie (BE), 3\% in Fiscale Economie (FE), 4\% in Internationaal Management (IM) en 5\% in andere economische opleidingsrichtingen (Ec-overig). De onderzoekspopulatie wordt niet alleen gedomineerd door bedrijfseconomen maar ook door mannen (76\%, vorig meetjaar $77 \%$ ). De gemiddelde leeftijd op het moment van enquêteren bedraagt evenals vorig meetjaar 26 jaar. Veel afgestudeerden beschikken over extra kwalificaties die men vóór of tijdens de economieopleiding heeft opgedaan, en wel in de vorm van een voltooide opleiding in het hoger onderwijs voordat men economie is gaan studeren $(20 \%$, vorig meetjaar $18 \%)$, voor het vakgebied relevante werkervaring (54\%, vorig meetjaar $44 \%$ ) en/of bestuurlijke ervaring ( $58 \%$, vorig meetjaar $60 \%)$.

Deelname aan verder onderwijs

Eén op iedere vijf afgestudeerden ( $21 \%$, vorig meetjaar $18 \%$ ) heeft na het afstuderen gedurende kortere of langere tijd verder onderwijs gevolgd (cursorisch onderwijs en bedrijfsopleidingen niet meegerekend). Afgestudeerden IM en FE gaan minder vaak verder onderwijs volgen dan de afgestudeerden van andere economische opleidingen.

\section{Maatschappelijke positie}

De meeste (78\%) economen zijn na het afstuderen niet of in totaal hooguit drie maanden werkzoekend geweest. Dit is een verbetering ten opzichte van vorig meetjaar (72\%). Jongere afgestudeerden blijken sneller werk te vinden dan ouderen. Ook afgestudeerden die beschikken over extra kwalificaties, bijvoorbeeld in de vorm van bestuurlijke ervaring, vinden sneller een baan. Vergeleken met algemeen economen (de referentiegroep in de analyse) vinden afgestudeerden IM minder snel een baan. 
Op het moment van onderzoek heeft $91 \%$ van de afgestudeerden een betaalde baan van minimaal 12 uur per week. Dit is hoger dan de $85 \%$ bij de vorige meting. Het percentage geregistreerd werklozen bedraagt op dat moment $5 \%$. Dit is aanzienlijk lager dan de $10 \%$ bij de vorige enquête.

\section{Werkkring}

Evenals bij de vorige enquête het geval was, zijn reageren op een advertentie (26\%) en open solliciteren (23\%) de twee belangrijkste kanalen waarmee pas-afgestudeerde economen een werkkring vinden. Vorig jaar vond eveneens $26 \%$ een baan door op een advertentie te reageren. Wel lijkt het erop dat economen zich bij het zoeken naar werk aktiever zijn gaan opstellen: het aandeel van ongevraagd solliciteren (open solliciteren) is namelijk toegenomen van $18 \%$ vorig jaar naar $23 \%$ dit jaar.

Driekwart (76\%, vorig jaar $71 \%$ ) van de betaald-werkende economen komt terecht in grote organisaties met minimaal 100 werknemers. De meesten $(78 \%)$ werken in dezelfde provincie waar men heeft gestudeerd of in een daaraan grenzende provincie. Vorig jaar was dit $83 \%$. (evenals vorig jaar werkt $3 \%$ in het buitenland). Zo'n anderhalf jaar na het afstuderen is $44 \%$ (vorige enquête $41 \%$ ) van de betaaldwerkende oudstudenten al eens van werkkring veranderd. De mobiliteit is dus toegenomen.

\section{Functie-eisen}

De helft (53\%) van de betaald-werkende economen heeft een functie op academisch niveau. Dit is aanzienlijk lager dan bij de vorige enquête (61\%). Driekwart $(77 \%)$ heeft functies die passen bij hun opleidingsrichting (vorig jaar $80 \%$ ). Een kwart $(27 \%$, vorig jaar $30 \%)$ heeft een functie waarvoor werkervaring is vereist. Een op de vijf (21\%) afgestudeerde oefent een leidinggevende functie uit (vorig meetjaar $23 \%$ ).

\section{Arbeidsvoonwaarden}

Evenals vorig jaar (95\%) hebben vrijwel alle (96\%) betaald-werkende afgestudeerden een full-time baan (> 32 uur per week). Ruim de helft $(56 \%)$ heeft een vaste aanstelling (vorig jaar 58\%). Het gemiddeld bruto maandinkomen is licht gedaald van fl. 3.930 vorig jaar naar fl. 3.890 ,- dit jaar.

\section{Succesbepalende factoren bij de arbeidsmarktintrede}

In dit rapport zijn twee dimensies van de transitie van studie naar werk nader geanalyseerd, namelijk de kans op werk en kwaliteit van het werk. De kans op werk is geanalyseerd aan de hand van de volgende twee indicatoren:

- het snel (binnen drie maanden) vinden van werk; 
- het hebben van een vaste aanstelling.

De kwaliteit van het werk is geanalyseerd aan de hand van vier indicatoren:

- het hebben van een baan waarvoor een opleiding op academisch niveau is vereist:

- het hebben van werk waarvoor de eigen- of een daaraan verwante opleidingsrichting is vereist;

- het uitoefenen van een leidinggevende functie;

- de hoogte van het bruto uurloon.

Als verklarende variabelen voor de kans op werk en kwaliteit van het werk zijn enkele persoons- en kwalificatiekenmerken, de werkregio alsmede enkele kenmerken van de loopbaan, het marktsegment en de functie in de analyses opgenomen.

\section{Invloed van persoonskenmerken op arbeidsmarktsucces}

Het geslacht blijkt niet van invloed te zijn op de kans op werk noch op de kwaliteit van het werk dat men krijgt. In de uitgevoerde analyses van de desbetreffende indicatoren kon althans geen significant effect van het geslacht worden vastgesteld.

Oudere afgestudeerden zijn langer werkzoekend en hebben een grotere kans om werk te krijgen buiten het eigen beroependomein dan jongere afgestudeerden. Mogelijk zijn de oudere afgestudeerden langer werkzoekend omdat zij minder snel een baan accepteren dan jongeren. Oudere afgestudeerden hebben namelijk vaker een vaste aanstelling, een leidinggevende functie en een hoger inkomen.

Invloed van kwalificaties op arbeidsmarktsucces

De economen die voorafgaand aan hun economie-opleiding al een wetenschappelijke of hogere beroepsopleiding hebben voltooid, zijn in het voordeel ten opzichte van de andere economen wat betreft de kans om snel aan het werk te komen en werk te krijgen in het eigen domein. Daarbij komt dat zij meer verdienen.

De afgestudeerden die vóór of tijdens de economie-opleiding bestuurlijke ervaring of voor het vakgebied relevante werkervaring hebben opgedaan, vinden niet alleen sneller werk maar ook vaker werk dat past bij het genoten opleidingsniveau. Daarnaast hebben zij meer kans op een leidinggevende functie. Afgestudeerden met bestuurlijke ervaring verwerven bovendien een hoger inkomen.

Door de economie-studie te combineren met een betaalde baan en door stage te lopen, stijgt de kans om snel werk te vinden.

De kans om snel aan het werk te komen en werk te krijgen in het eigen beroependomein wordt ook bepaald door de gevolgde economische opleidingsrichting. Zo komt in de analyses naar voren dat afgestudeerden IM, ondanks het feit dat zij relatief 
vaak stage hebben gelopen, het langst naar werk zoeken en fiscaal economen het vaakst werk vinden dat past bij de gevolgde opleidingsrichting.

Invloed loopbaan op arbeidsmarktsucces

De kans op een vaste baan en werk dat past bij het niveau en de richting van de gevolgde opleiding neemt toe naarmate men langer op de arbeidsmarkt verblijft.

Een langere zoektijd naar werk verlaagt de kans op een vaste aanstelling en een leidinggevende functie. Daarnaast verdienen degenen die langer naar werk hebben moeten zoeken minder.

Invloed werkregio op arbeidsmarktsucces

Vergeleken met de referentie-econoom die in Noordoost-Nederland werkt, hebben de werkende economen in Zuid-Nederland minder kans op een vaste aanstelling en de in West-Nederland en het buitenland werkende economen meer kans op werk dat past bij het niveau van een academische opleiding. De in het buitenland werkende economen verdienen bovendien meer.

\section{Invloed marktsegment op arbeidsmarktsucces}

Economen die een baan hebben gevonden bij een grote organisatie (minimaal 100 personeelsleden) verdienen meer en hebben meer kans dat het werk past bij het niveau van een academische opleiding. Daar staat evenwel een geringere kans op een leidinggevende functie tegenover.

Verder blijkt dat men in de profit sector meer kans op een vaste baan heeft dan in non-profit organisaties.

Invloed functiekenmerken op inkomen

Tot slot is gebleken dat een vaste aanstelling, part-time werk, werk op academisch niveau, leidinggevend werk, een functie waarvoor werkervaring is vereist en werk dat aansluit bij de gevolgde opleidingsrichting samengaat met een hoger uurloon.

\section{Aansluiting opleiding-werk}

Bij alle opleidingsrichtingen kan worden geconstateerd dat een juiste werkhouding volgens de afgestudeerden het meest belangrijk is om het beroep goed te kunnen uitoefenen. Verder blijkt dat kennis en vaardigheden op het gebied van commercieel management meer dan gemiddeld belangrijk zijn voor afgestudeerden IM, kennis en 
vaardigheden met betrekking tot dataverwerking en -beheer voor afgestudeerden BIK en theoretische en praktische vakkennis voor fiscaal economen.

Naar de mening van de oudstudenten zouden mondelinge en schriftelijke presentatie, onderhandelingstechnische en commerciële vaardigheden, informatie- en communicatietechnologie en de praktische toepassing van vakkennis best wat meer aandacht mogen krijgen tijdens de opleiding. De vakkennis zelf komt volgens de afgestudeerden voldoende aan bod tijdens de opleiding.

\section{Bijscholing}

Evenals vorig jaar (82\%) kwalificeert de overgrote meerderheid (83\%) van de betaald-werkende afgestudeerden de aansluiting tussen opleiding en werk als goed of voldoende. Dit laat onverlet dat bijna de helft (45\%) van de afgestudeerden aanvullende opleidingen of cursussen heeft gevolgd. De meeste $(52 \%)$ deelnemers aan bijscholing volgen bijscholing om zich verder te specialiseren binnen het eigen vakgebied. Vorig jaar was dit $45 \%$.

\section{Opleiding achteraf bezien}

De meeste afgestudeerden vinden dat het economie-onderwijs tekort schiet wat de oriëntatie op het toekomstige beroepenveld betreft. De samenhang in onderwijsonderdelen van de opleiding, de keuzemogelijkheden in de studie, de mate waarin de opleiding is gespecialiseerd, de zwaarte van de opleiding en de studiebegeleiding hoeven volgens de meeste afgestudeerden niet te worden bijgesteld. Dit laat onverlet dat nog altijd zo'n vier op iedere tien afgestudeerden van mening zijn dat de samenhang tussen de onderwijsonderdelen voor verbetering vatbaar is, dat een op de drie afgestudeerden vindt dat er meer studiebegeleiding nodig is, en dat een op de vijf afgestudeerden meer keuzemogelijkheden in de studie wenst of van mening is dat de opleiding meer gespecialiseerd zou kunnen zijn. Een opmerkelijk resultaat is verder dat maar liefst een derde van de afgestudeerden van mening is dat de opleiding zwaarder zou mogen worden, terwijl vrijwel geen enkele afgestudeerde zegt dat de opleiding minder zwaar zou moeten zijn.

Een ruime meerderheid ( $82 \%$, vorig meetjaar: $81 \%$ ) zou, achteraf bezien, opnieuw dezelfde opleiding kiezen. Evenals bij de vorige enquête betreurt slechts $4 \%$ de destijds genomen studiekeuze: zij zouden, achteraf bezien, niet zijn gaan studeren $(2 \%$, vorig jaar $1 \%)$ of een niet-universitaire opleiding zijn gaan volgen $(2 \%$, vorig jaar 3\%). 
In overleg met de participerende faculteiten is besloten om eventuele sexeverschillen bij de transitie van opleiding naar beroep als thema nader te onderzoeken. Hieruit komt als algemene conclusie naar voren dat vrouwelijke en mannelijke economen nauwelijks van elkaar verschillen wat betreft de kwalificaties waarmee zij de arbeidsmarkt betreden, de kans op werk en de kwaliteit van het gevonden werk. Mannen blijken wel vaker leidinggevende functies te bekleden omdat zij gemiddeld wat ouder zijn, meer over bestuurlijke ervaring beschikken en vaker in kleinere organisaties werken. Deze aspecten vergroten de kans op een leidinggevende functie. 


\section{Inleiding}

\subsection{Opzet WO-Scanner Economie}

In opdracht van de economische faculteiten van de Erasmus Universiteit Rotterdam (EUR) en de Katholieke Universiteit Brabant (KUB) en het College van Bestuur van de Universiteit Maastricht (UM) is eind 1995 - begin 1996 voor de tweede keer de WO-Scanner Economie uitgevoerd. Het onderzoeksproject is gericht op het in kaart brengen van de arbeidsmarktintrede van afgestudeerde economen en bestaat uit een schriftelijke enquête. Deze wordt jaarlijks gehouden in de maanden oktoberjanuari onder alle afgestudeerden van het daaraan voorafaande jaar, hetgeen neerkomt op zo'n anderhalf jaar na het afstuderen (afhankelijk van de maand waarin men is afgestudeerd en de maand waarin men de vragenlijst heeft ingevuld). De enquête geeft aldus informatie over de startfuncties van de afgestudeerden. De gehanteerde vragenlijst bevat vragen over de persoon, de afgesloten opleiding, de vooropleiding, de eventuele werk- en bestuurservaring vóór het afstuderen, de belangrijkste activiteiten na het afstuderen tot het moment van enquêteren, de huidige arbeidsmarktpositie, eventueel gevolgd onderwijs na het afstuderen en, bij betaald-werkenden, enkele kenmerken van de huidige functie en van de organisatie waarin men werkzaam is alsmede vragen over de aansluiting van de genoten opleiding op de beroepspraktijk. De definitie en classificatie van de variabelen sluit waar mogelijk aan bij de gangbare indelingen die worden gehanteerd door het Centraal Bureau voor de Statistiek (CBS).

In het tweede uitvoeringsjaar, eind 1995/begin 1996, zijn alle economen schriftelijk benaderd, die in het studiejaar 1993/1994 aan de EUR danwel in kalenderjaar 1994 aan de KUB en UM hun diploma hebben behaald. Het betreft in totaal 1798 afgestudeerde economen. Na de eerste verzending van de vragenlijst is een rappel verstuurd aan de afgestudeerden die toen nog niet hadden gereageerd en is, waar nodig, een tweede schriftelijk rappel uitgevoerd. Tevens heeft een telefonisch rappel plaatsgevonden. Uiteindelijk hebben 1097 afgestudeerden de vragenlijst ingevuld geretourneerd, hetgeen neerkomt op een respons van $61 \%$. De inname en verwerking van de enquêteformulieren is begin februari 1996 definitief gestaakt.

De deelnemende faculteiten ontvangen in de eerste plaats een vertrouwelijke faculteitsrapportage waarin per opleiding de resultaten van de eigen faculteit en de desbetreffende totale gegevens van de deelnemende faculteiten samen staan vermeld. Op deze wijze kan de faculteit de positie van haar eigen opleiding ten opzichte van het totale resultaat voor die opleiding bepalen. Het thans voorliggende disciplinerapport economie bevat de resultaten van de drie deelnemende economische faculteiten samen. 
Inmiddels is voor het uitvoeringsjaar 1996/1997 de deelname aan de WO-Scanner Economie belangrijk verbreed door de participatie van de economische faculteiten van de Universiteit van Amsterdam (UvA) en de Vrije Universiteit (VU). Dit betekent dat de WO-Scanner Economie voor de komende meting vrijwel alle pas afgestudeerde economen zal omvatten met uitzondering van de Rijksuniversiteit Groningen.

De inhoudelijke opzet van de WO-Scanner Economie kan als volgt worden beschreven. Afgestudeerden betreden de arbeidsmarkt met een bepaalde bagage. Deels betreft dit een aantal niet te beïnvloeden persoonskenmerken (geslacht en leeftijd), deels betreft dit de kwalificaties die zij tijdens de studie economie hebben opgedaan (de gevolgde opleidingsrichting) en eventuele extra kwalificaties die zij vóór of tijdens de studie economie hebben verworven (vooropleiding, werkervaring en bestuurlijke ervaring). Deze persoons- en kwalificatiekenmerken worden in paragraaf 1.2 beschreven. Zowel de persoonskenmerken als de kwalificatiekenmerken worden in dit onderzoek als achtergrondvariabelen gebruikt ter verklaring van eventuele verschillen op de arbeidsmarkt.

In paragraaf 2.1 wordt niet alleen de maatschappelijke positie op het moment van enquêteren (zo'n anderhalf jaar na afstuderen) maar ook de verschuivingen in het eerste jaar na het afstuderen aangegeven.

Om zicht te krijgen op de kans op werk van de afgestudeerden zijn in paragraaf 2.2 twee indicatoren gebruikt, namelijk het aantal maanden dat men na het afstuderen in totaal werkzoekend is geweest en de werkloosheid op het moment van enquêteren. In paragraaf 2.3 wordt nader ingegaan op de deelname aan verder regulier onderwijs.

Hoofdstuk 3 gaat in op de banen van de betaald-werkende economen. Het hoofdstuk start in paragraaf 3.1 met een beschrijving van de wijze waarop de economen aan hun baan zijn gekomen. In aansluiting hierop wordt in paragraaf 3.2 nagegaan in wat voor werkorganisaties zij terechtkomen. Deze worden getypeerd naar personeelsomvang, bedrijfssector en regio. Vervolgens wordt de kwaliteit van het werk aan de hand van een aantal indicatoren in kaart gebracht. Daartoe wordt in paragraaf 3.3 eerst gekeken naar het opleidingsniveau, de opleidingsrichting en de eventuele werkervaring die voor de functie is vereist. Tevens wordt nagegaan of het een leidinggevende functie betreft. De bespreking van de kwaliteit van het werk wordt in paragraaf 3.4 vervolgd aan de hand van een aantal arbeidsvoorwaarden waarvan er twee nauw verwant zijn aan de kans op werk, namelijk de mate van werkzekerheid en arbeidsparticipatie. In paragraaf 3.4 wordt in dit verband gekeken naar het aandeel van betaald-werkende afgestudeerden met een vaste aanstelling en naar het aandeel van full-time aanstellingen. Als laatste van de arbeidsvoorwaarden wordt gekeken naar de hoogte van het inkomen. 
De aansluiting tussen de economie-opleiding en het werk dat de economen uitoefenen, vormt eveneens een dimensie van de transitie van opleiding naar arbeidsmarkt. In hoofdstuk 4 geven de betaald-werkende economen eerst hun algemeen oordeel over deze aansluiting. Vervolgens wordt in paragraaf 4.1 nagegaan welke kennis en vaardigheden van belang zijn voor een goede beroepsuitoefening, waarbij de economen tevens aangeven of deze kennis en vaardigheden wel voldoende aan bod zijn gekomen tijdens hun opleiding. In aansluiting hierop wordt in paragraaf 4.2 aandacht geschonken aan de behoefte en deelname aan bijscholing.

In hoofdstuk 5 kijken de afgestudeerden terug op hun opleiding. Eerst geven de afgestudeerden aan in welke richting een aantal aspecten van het economieonderwijs naar hun mening zou moeten worden bijgesteld. Tot slot wordt ingegaan op de vraag of de afgestudeerden, achteraf bezien, wederom dezelfde economieopleiding zouden kiezen.

In hoofdstuk 6 worden eventuele sexeverschillen bij de transitie van het economieonderwijs naar het werk als specifiek thema behandeld.

\subsection{Samenstelling onderzoekspopulatie}

Aan de eind 1995/begin 1996 gehouden enquête hebben in totaal 1097 economen meegewerkt, namelijk 481 afgestudeerden van de EUR (44\%), 425 afgestudeerden van de KUB (39\%) en 191 afgestudeerden van de UM (17\%). Deze respondenten zijn als volgt over de economische opleidingen verdeeld: bestuurlijke informatiekunde $(4 \%)$, econometrie $(9 \%)$ en economie $(86 \%)$. Vanwege het grote aantal afgestudeerden zal de opleiding economie verder worden onderverdeeld in de volgende opleidingsrichtingen: algemene economie, bedrijfseconomie, fiscale economie en internationaal management. Vanwege de kleine aantallen afgestudeerden worden de opleidingen bestuurlijke informatiekunde, econometrie en fiscale economie niet verder uitgesplitst naar opleidingsrichting. Tabel 1.1 geeft de verdeling van de 1097 respondenten over de in dit rapport onderscheiden opleidingen.

Tabel 1.1

Gevolgde opleidingen

\begin{tabular}{lc}
\hline & $4 \%$ \\
Bestuurlijke informatiekunde (BIK) & $9 \%$ \\
Econometrie (Ectrie) & $10 \%$ \\
Algemene economie (AE) & $66 \%$ \\
Bedrijfseconomie (BE) & $3 \%$ \\
Fiscale economie (FE) & $4 \%$ \\
Internationaal Management (IM) & $5 \%$ \\
Economie: overig (Ec-overig) & 1097 \\
Totaal n (= 100\%) & \\
\hline
\end{tabular}


Binnen de categorie Ec-overig (5\%) vallen 55 afgestudeerden, die de volgende opleidingen hebben gevolgd:

- kwantitatieve economie 2

- sociologische economie 12

- verkeer- en vervoerseconomie $\quad 12$

- economie, Europese integratie 9

- staatkundige economie 5

- vrij doctoraal economie 8

- richting binnen de opleiding economie onbekend 5

- economische opleiding onbekend 2

In deze paragraaf worden de respondenten eerst beschreven aan de hand van twee persoonskenmerken, namelijk het geslacht en de leeftijd op het moment van enquêteren. Vervolgens worden de additionele kwalificaties besproken, die vóór of tijdens de studie zijn behaald. Het gaat hierbij om zowel formele als informele kwalificaties die het functioneren binnen arbeidsorganisaties en op de arbeidsmarkt beïnvloeden. Formele kwalificaties zijn kwalificaties die men in het reguliere onderwijs verwerft, terwijl informele kwalificaties worden opgedaan buiten het reguliere onderwijs, bijvoorbeeld in een werkkring of in een bestuurlijke functie.

\section{Geslacht}

Tabel 1.2 laat zien dat economische opleidingen 'mannenstudies' zijn. Slechts een kwart $(24 \%)$ van de afgestudeerden bestaat uit vrouwen. Bij de vorige enquête bedroeg het aandeel van vrouwen $23 \%$. Bij BIK zijn vrouwen nog het sterkst ondervertegenwoordigd.

Leeftijd

De gemiddelde leeftijd op het moment van enquêteren, dat wil zeggen zo' $n$ anderhalf jaar na afstuderen, bedraagt 26,4 jaar (tabel 1.2). Bij de vorige enquête was dit 26,2 jaar. Econometristen en afgestudeerden BIK zijn gemiddeld het jongst; afgestudeerden FE het oudst.

Vooropleiding

Tabel 1.3 geeft een beeld van de hoogste met diploma voltooide vooropleiding alvorens men economie is gaan studeren. Naar voren komt dat éen op iedere vijf afgestudeerden (19\%) eerst een HBO-opleiding heeft voltooid alvorens een economische opleiding aan de universiteit te gaan studeren. Dit is iets meer dan bij de vorige enquête $(17 \%)$. De geënquêteerde econometristen zijn allen vanuit het VWO ingestroomd. Van de afgestudeerden van $\mathrm{BE}$ is relatief het hoogste percentage afkomstig van het $\mathrm{HBO}$, namelijk $25 \%$. 


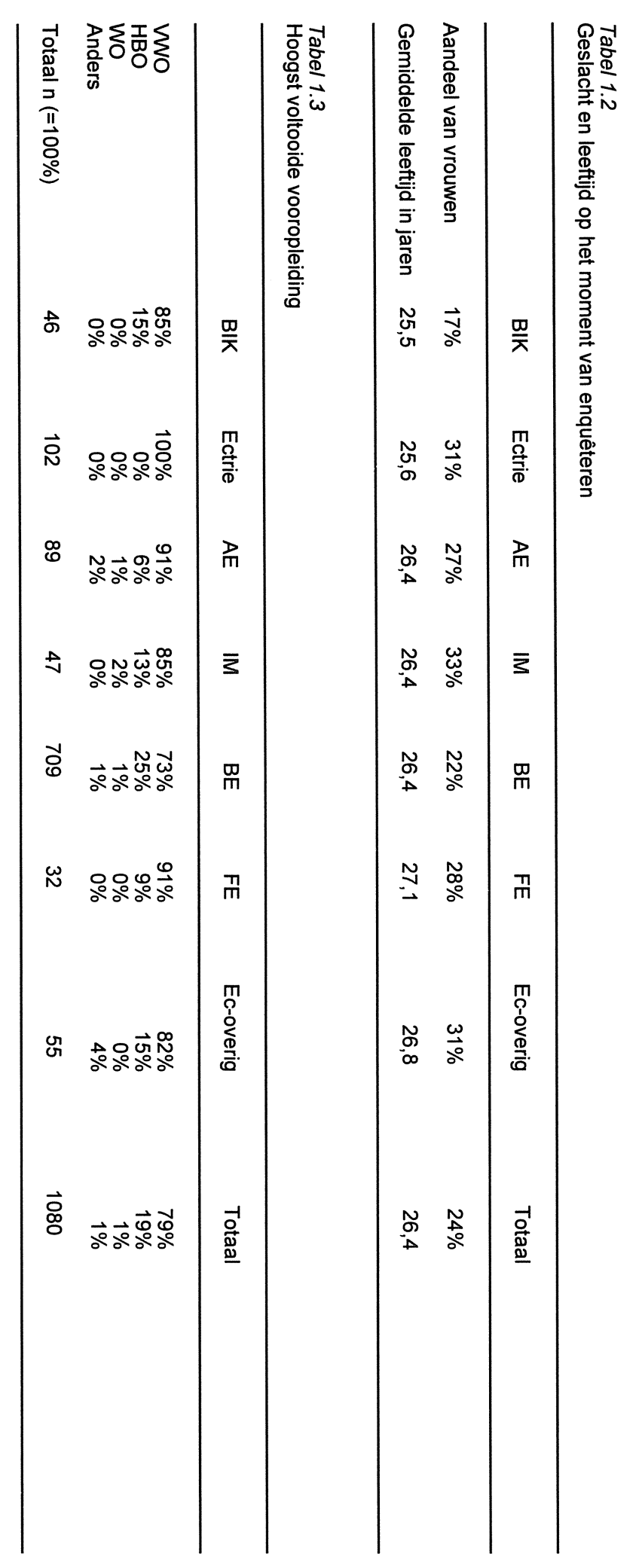




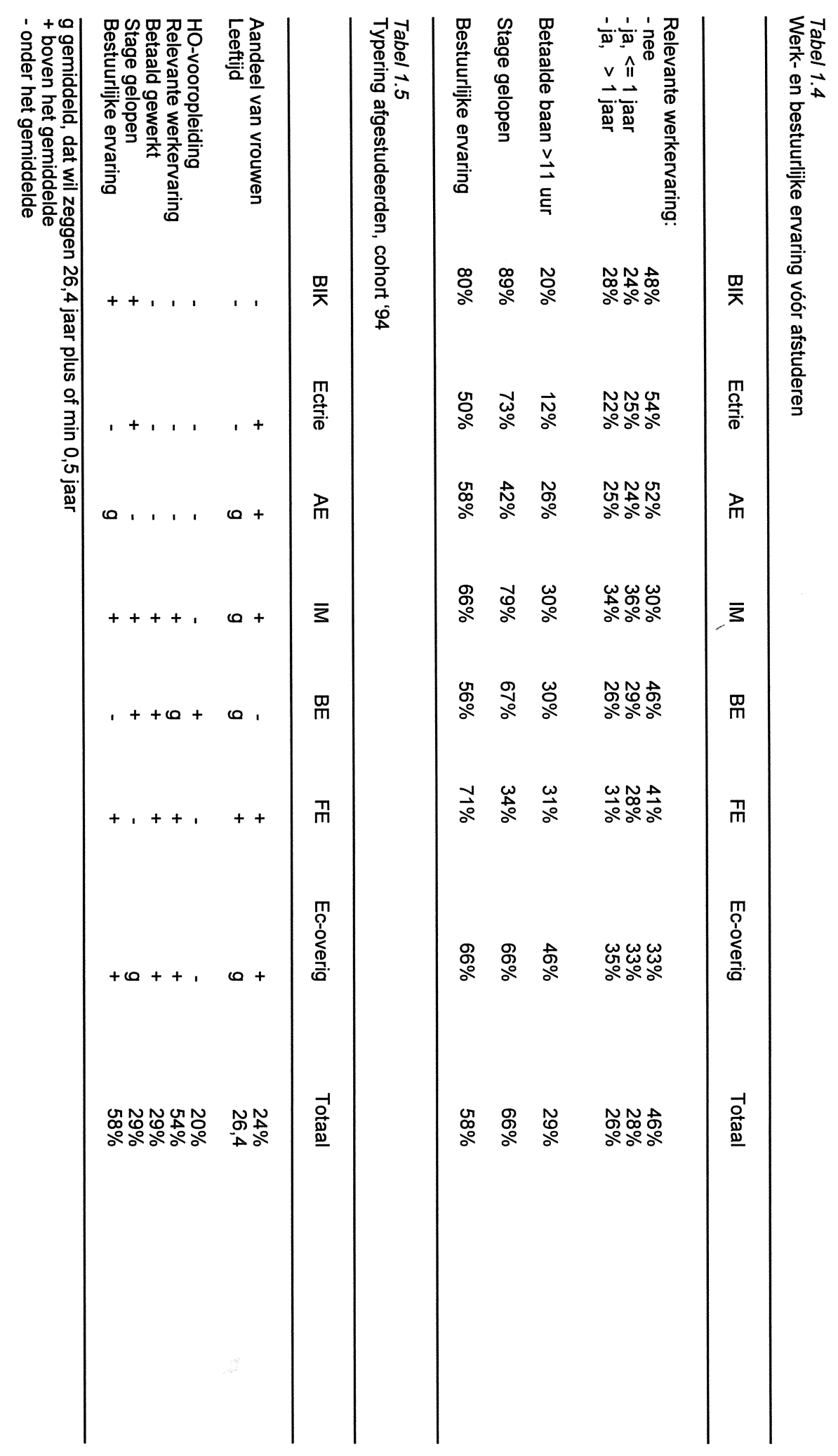




\section{Werkervaring}

Aan de afgestudeerden is gevraagd of zij vóór of tijdens de economie-studie betaalde of onbetaalde werkervaring (exclusief stages) hebben opgedaan die relevant is voor hun vakgebied. Dit blijkt bij ruim de helft (54\%) van de afgestudeerden het geval te zijn. Dit is aanzienlijk hoger dan de $44 \%$ bij de vorige enquête. Tabel 1.4 laat verder zien dat het aandeel van afgestudeerden met relevante werkervaring het hoogst is bij IM.

Aan de afgestudeerden is tevens gevraagd of zij gedurende hun gehele economie studie een betaalde baan hebben gehad voor tenminste 12 uur per week. Dit blijkt bij ruim een kwart (29\%) van de respondenten het geval te zijn geweest (tabel 1.4).

\section{Stage ervaring}

Twee van de drie economen (66\%) heeft tijdens de opleiding stage gelopen. Afgestudeerden BIK hebben het vaakst stage gelopen en fiscaal economen het minst vaak (tabel 1.4).

\section{Bestuurlijke ervaring}

In de enquête is ook gevraagd of men vóór of tijdens de economie-studie bestuurlijke ervaring heeft opgedaan, bijvoorbeeld voor een vereniging, faculteit of belangengroepering. Tabel 1.4 laat zien dat ruim de helft $(58 \%)$ op het moment van afstuderen over enigerlei vorm van bestuurlijke ervaring beschikt (bij de vorige enquête bedroeg het aandeel met bestuurlijke ervaring 60\%). Het aandeel van afgestudeerden met bestuurlijke ervaring is het hoogst bij BIK.

\section{Resumé}

Resumerend kunnen de afgestudeerden van de onderscheiden opleidingen als volgt worden getypeerd (tabel 1.5).

- Afgestudeerden BIK zijn jonger dan gemiddeld en vaker man. Eveneens jonger dan gemiddeld, maar vaker vrouw zijn afgestudeerden econometrie.

- Afgestudeerden AE, IM en Ec-overig wijken qua leeftijd niet af van het gemiddelde, maar zijn wel vaker dan gemiddeld vrouw. Ook afgestudeerden BE wijken qua leeftijd niet af van het gemiddelde maar zijn vaker dan gemiddeld man.

- Afgestudeerden FE zijn niet alleen ouder dan gemiddeld maar tevens vaker dan gemiddeld vrouw.

Met betrekking tot de additionele kwalificaties waarmee men de arbeidsmarkt betreedt, kan worden geconstateerd dat afgestudeerden BIK vaker dan gemiddeld over bestuurlijke ervaring beschikken. Afgestudeerden IM, FE en Ec-overig beschik- 
ken daarnaast vaker dan gemiddeld over menselijk kapitaal in de vorm van werkervaring die relevant is voor hun vakgebied. Afgestudeerden $\mathrm{BE}$ beschikken vaker dan gemiddeld over additionele kwalificaties in de vorm van een hoger onderwijsdiploma voordat zij economie zijn gaan studeren. 


\section{Intrede op de arbeidsmarkt}

\subsection{Verschuivingen in maatschappelijke positie na afstuderen}

In deze paragraaf wordt ingegaan op de verschuivingen in de maatschappelijke positie, gemeten één maand, drie maanden, zes maanden en twaalf maanden na afstuderen alsmede op het moment van enquêteren. Het gaat hierbij om de maatschappelijke positie die volgens de respondenten hun dagelijkse situatie in de desbetreffende maand het beste weergeeft. Tabel 2.1 geeft hiervan een beeld. Onder 'betaald werk' wordt hier begrepen: tenminste voor 12 uur per week. Indien de respondent in een bepaalde maand minimaal 12 uur per week betaald werkte, moest men voor die maand altijd de categorie 'betaald werk' aankruisen. Indien de respondent minder dan 12 uur per week betaald werkte, kon men kiezen voor één van de andere antwoordcategorieën.

Tabel 2.1 laat zien dat de helft van de afgestudeerden al binnen één maand na afstuderen een betaalde baan heeft. Het aandeel van betaald-werkenden neemt daarna gestaag toe. Op het moment van enquêteren, zo'n anderhalf jaar na afstuderen, bedraagt het aandeel van afgestudeerden met een betaalde baan van minimaal 12 uur per week $91 \%$. Dit is meer dan de $85 \%$ bij de vorige enquête. Het aandeel van werkzoekenden daalt sterk en wel van $26 \%$ direct na afstuderen tot $5 \%$ anderhalf jaar later. Het aandeel van dienstplichtigen neemt gedurende de eerste zes maanden sterk toe, waarna een sterke daling optreedt.

In de eerste maand na het afstuderen geeft $8 \%$ als voornaamste dagtaak 'studie' op. Mogelijk gaat het bij een aantal van deze afgestudeerden niet om een vervolgstudie, maar nog steeds om de aan de faculteit gevolgde opleiding. Hoe het ook zij, na anderhalf jaar is het aandeel van verder studerenden gedaald tot één procent. Het aandeel van degenen die een 'andere situatie' hebben opgegeven, laat een gestaag dalend verloop zien. Hiertoe behoren onder meer afgestudeerden die eerst met vakantie zijn gegaan, huisvrouwen en -mannen en onbetaald-werkenden.

\subsection{Kans op werk}

In deze rapportage wordt de kans op een betaalde baan weergegeven middels twee indicatoren, namelijk het aantal maanden dat men na het afstuderen in totaal werkzoekend is geweest en de omvang van de werkloosheid op het moment van enquêteren. In aansluiting hierop wordt nagegaan welke kenmerken van afgestudeerden van invloed zijn op het al dan niet snel vinden van werk. 


\section{Werkzoekend tijdens intredeperiode}

Het totaal aantal maanden dat men na het afstuderen naar betaald werk heeft gezocht, geeft een indicatie van de mate waarin de intrede op de arbeidsmarkt meer of minder succesvol is verlopen. Onder werkzoekend wordt hier begrepen: 'werkzoekend, terwijl geen of minder dan 12 uur per week betaald werk wordt verricht'. Tabel 2.2 schetst de mate van succes waarmee afgestudeerden de arbeidsmarkt hebben betreden. In de tabel zijn uitsluitend afgestudeerden opgenomen, die zich na het afstuderen op enigerlei moment hebben aangeboden op de arbeidsmarkt: zij hebben in die periode ooit betaald werk verricht en/of zijn ooit werkzoekend geweest.

Tabel 2.2 laat zien dat de helft (53\%) van alle afgestudeerden niet werkzoekend is geweest tijdens de intredeperiode, dat wil zeggen tussen de maand van afstuderen en de enquêtemaand. Dit is een verbetering ten opzichte van de vorige enquête (48\% niet werkzoekend geweest). Bij afgestudeerden IM is de arbeidsmarktintrede het moeizaamst verlopen. Afgestudeerden BIK hebben het snelst werk gevonden.

\section{Werkloosheid op moment van enquêteren}

Bij het bespreken van de verschuivingen in de maatschappelijke positie na afstuderen en het zoeken naar werk tijdens de intredeperiode is steeds het begrip 'werkzoekende' gebruikt. Het gaat hierbij om afgestudeerden die van zichzelf vinden dat zij in een bepaalde maand werkzoekend zijn geweest, terwijl zij in de betreffende maand geen betaald werk voor tenminste 12 uur per week hebben gehad.

De in tabel 2.2 gepresenteerde werkloosheidspercentages hebben echter betrekking op de definitie van 'geregistreerde werkloosheid', zoals die door het CBS wordt gehanteerd. Conform deze CBS-definitie worden afgestudeerden met een leeftijd van $16 \mathrm{t} / \mathrm{m} 64$ jaar gerekend tot de geregistreerde werklozen wanneer zij:

- zijn ingeschreven bij het arbeidsbureau, èn

- tenminste 12 uur per week betaald werk willen verrichten, èn

- op het enquêtemoment geen betaald werk voor tenminste 12 uur per week hebben, èn

- beschikbaar zijn voor een baan van tenminste 12 uur per week (d.w.z. binnen twee weken kunnen beginnen of anders binnen drie maanden in verband met opzegtermijn huidige werkkring, het afronden van vrijwilligerswerk, het regelen van kinderopvang, vakantie of ziekte), òf:

- betaald werk hebben aanvaard waarvoor men tenminste 12 uur per week gaat werken. 


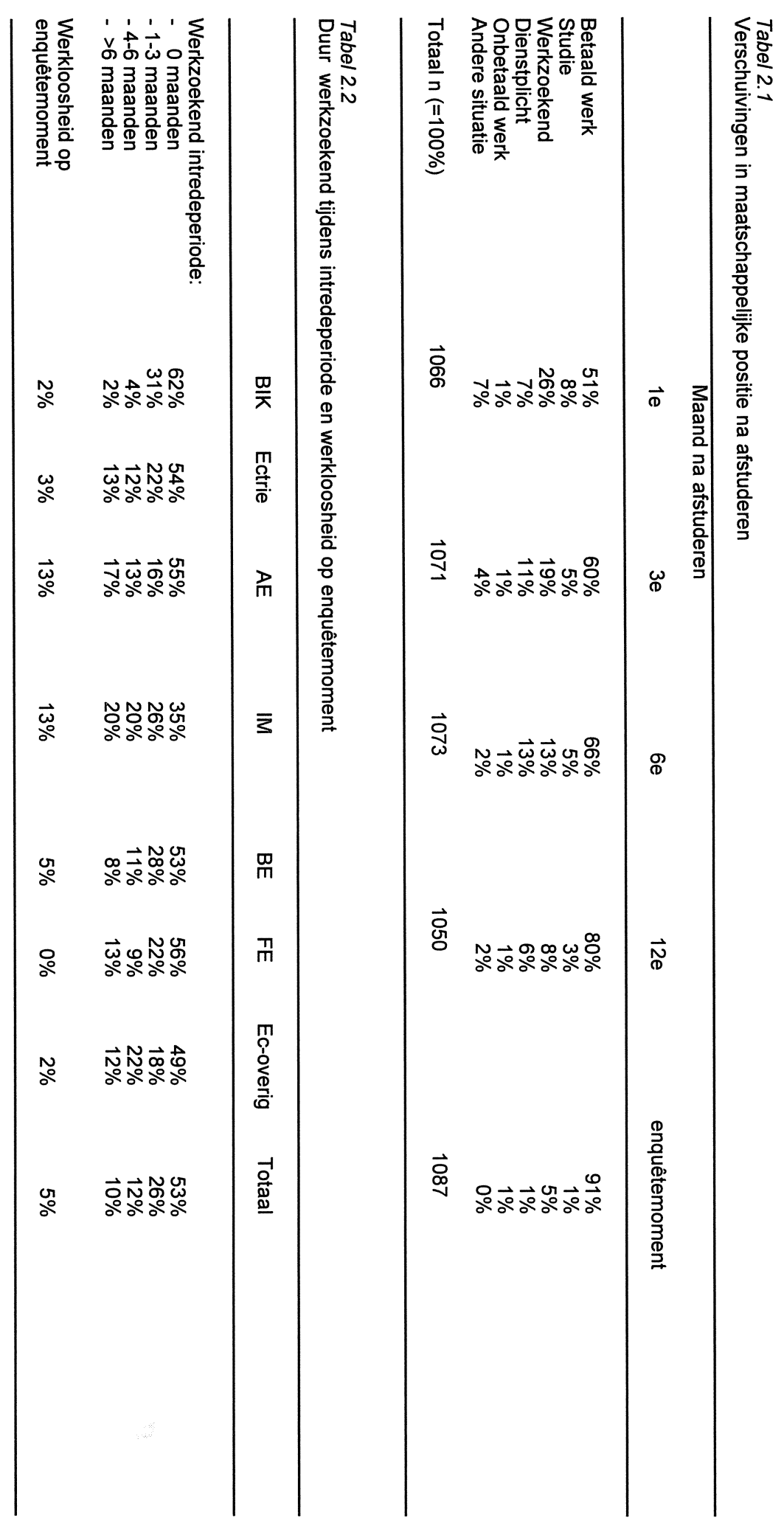


Voor het berekenen van het werkloosheidspercentage wordt het aantal geregistreerde werkloze afgestudeerden uitgedrukt als percentage van de afgestudeerden die tot de beroepsbevolking behoren. Welnu, conform CBS-definitie worden afgestudeerden tot de beroepsbevolking gerekend wanneer zij:

- tenminste 12 uur per week betaald werken, òf

- militaire of vervangende dienstplicht vervullen, òf

- betaald werk hebben aanvaard waarvoor zij tenminste 12 uur per week gaan werken, òf

- verklaren tenminste 12 uur per week betaald werk te willen verrichten, daarvoor beschikbaar zijn èn activiteiten ontplooien om betaald werk voor tenminste 12 uur per week te vinden.

Aldus gedefinieerd, bedraagt de werkloosheid op het moment van enquêteren (zo'n anderhalf jaar na afstuderen) gemiddeld $5 \%$. Dit is beduidend lager dan de $10 \%$ van de vorige enquête, gemeten volgens dezelfde definitie. Het werkloosheidspercentage heeft dit meetjaar betrekking op de situatie eind 1995/begin 1996. Onder afgestudeerden van de opleidingsrichtingen $A E$ en $I M$ is de werkloosheid echter nog steeds zeer hoog namelijk $13 \%$. Vorig jaar bedroeg de werkloosheid onder elk van deze twee opleidingsrichtingen nog $15 \%$. Dat betekent dat de afgestudeerden van deze twee opleidingsrichtingen in veel mindere mate dan de overige opleidingsrichtingen hebben kunnen profiteren van de economische opleving. Wellicht hebben afgestudeerden $A E$ minder van de conjuncturele opleving kunnen profiteren omdat zij meer dan gemiddeld zijn aangewezen op de minder conjunctuurgevoelige non-profit sector. Van alle geënquêteerde economen komt $17 \%$ in de non-profit sector terecht; van de afgestudeerden $A E 42 \%$. Bij de relatief hoge werkloosheid onder afgestudeerden IM kan de onbekendheid bij potentiële werkgevers van deze nog relatief jonge opleiding een rol spelen. Van de onderzochte fiscaal economen blijkt niemand werkloos te zijn.

\section{Schatting van de kans op werk}

Met behulp van logistische regressie-analyse is nagegaan welke factoren van invloed zijn op het al dan niet snel vinden van werk. In de analyse heeft een afgestudeerde een goede kans op betaald werk wanneer hij of zij in de periode tussen afstuderen en de enquête niet of in totaal hooguit drie maanden op zoek is geweest naar betaald werk. De referentiegroep wordt gevormd door degenen die tijdens de periode tussen afstuderen en enquêteren in totaal langer dan drie maanden naar werk hebben gezocht. De analyse heeft uitsluitend betrekking op afgestudeerden die zich na het afstuderen ooit op de arbeidsmarkt hebben aangeboden: zij hebben in die periode ooit betaald werk verricht en/of zijn ooit werkzoekend geweest.

In de analyse is een aantal verklarende variabelen opgenomen waarvan wordt aangenomen dat zij de kans op het snel vinden van werk kunnen beïnvloeden, 
namelijk persoonskenmerken, additionele kwalificaties waarover afgestudeerden eventueel beschikken, de gevolgde opleiding en het aantal maanden tussen het moment van afstuderen en het moment van enquêteren. Het laatste kenmerk is in de analyse opgenomen om te kunnen corrigeren voor ongelijke perioden van arbeidsmarktintrede.

De in de analyse opgenomen persoonskenmerken betreffen het geslacht (geslacht: man) en de leeftijd op het moment van afstuderen (leeftijd). De eventuele extra kwalificaties, opgedaan vóór of tijdens de opleiding betreffen het reeds beschikken over een diploma van een opleiding in het hoger onderwijs voordat men aan de economische faculteit kwam studeren (HO-vooropleiding), het beschikken over bestuurlijke ervaring, het beschikken over voor het vakgebied relevante (on)betaalde werkervaring (exclusief stages): relevante werkervaring, het combineren van de gehele economie-opleiding met een betaalde baan (combinatie wo-werk) en het beschikken over stage-ervaring. In de analyse zijn de volgende dummy-variabelen voor de gevolgde opleiding opgenomen: bestuurlijke informatiekunde (BIK), Econometrie, algemene economie $(A E)$, internationaal management $(I M)$, bedrijfseconomie $(B E)$, fiscale economie $(F E)$ en de overige economische opleidingsrichtingen (Economie-overig).

De verklarende variabelen zijn geoperationaliseerd met behulp van dummy-variabelen, met uitzondering van de leeftijd in jaren (leeftijd) en het aantal maanden dat men reeds is afgestudeerd ( $n$ maanden afgestudeerd). Met betrekking tot de variabele leeftijd dient te worden vermeld dat $3 \%$ van de respondenten ouder dan 30 jaar is. Om te voorkomen dat de relatief hoge leeftijden van deze minderheid een te zware wissel zouden trekken op de analyseresultaten, is de leeftijd van deze dertigplussers op 31 jaar gesteld. In de schatting fungeerde $A E$ als referentie voor de gevolgde opleiding. Voor de preciese omschrijving van de verklarende variabelen wordt verwezen naar bijlage 1 .

Er wordt verondersteld dat de kans om snel werk te vinden per opleiding kan verschillen. Verder wordt verwacht dat vrouwen zich met minder succes dan mannen op de arbeidsmarkt aanbieden. Vanwege een aantal redenen mag worden verwacht dat jongeren een grotere kans hebben om snel een betaalde baan te krijgen dan ouderen. Jongeren zijn doorgaans flexibeler dan ouderen en kunnen zich daardoor wellicht makkelijker aanpassen aan de specifieke cultuur van een werkorganisatie. Bovendien zullen jongeren wellicht eerder bereid zijn om aanvullende (bedrijfsspecifieke) opleidingen te volgen, aangezien hun investering in aanvullend onderwijs gedurende een groter aantal arbeidsjaren tot een hoger inkomen zal leiden. Vanuit de werkgever gezien kunnen de in bedrijfsopleidingen geïnvesteerde tijd en kosten, middels de verwachte hogere arbeidsproductiviteit, bij jongeren over een groter aantal arbeidsjaren worden terugverdiend. Daarbij komt dat voor jongeren, vanwege het groter aantal arbeidsjaren dat zij nog voor zich hebben, een 
flexibeler loopbaanplanning mogelijk is: zij zijn makkelijker in lagere startfuncties inzetbaar om van daaruit, mede door het volgen van bedrijfsspecifieke opleidingen, door te stromen naar hogere functies in de organisatie. Extra kwalificaties in de vorm van het reeds beschikken over een HO-diploma vóórdat men economie gaat studeren alsmede voor het vakgebied relevante werkervaring en bestuurlijke ervaring, opgedaan vóór of tijdens de economiestudie vergroten iemands menselijk kapitaal, maken iemand productiever en daarmee voor een werkgever aantrekkelijker, waardoor de kans toeneemt om snel betaald werk te vinden.

Tabel 2.3

Logistische regressie-analyse van de kans om snel betaald werk te vinden

\begin{tabular}{|c|c|c|}
\hline & B & SE \\
\hline $\begin{array}{l}\text { Persoonskenmerken: } \\
\text { - geslacht: man } \\
\text { - leeftijd }\end{array}$ & $\begin{array}{l}.04 \\
-.25^{\star \star}\end{array}$ & $\begin{array}{l}.19 \\
.05\end{array}$ \\
\hline $\begin{array}{l}\text { Extra kwalificaties vóór afstuderen: } \\
\text { - HO-vooropleiding } \\
\text { - bestuurlijke ervaring } \\
\text { - relevante werkervaring } \\
\text { - combinatie wo-werk } \\
\text { - stage-ervaring }\end{array}$ & $\begin{array}{l}.83^{\star \star} \\
.34^{\star} \\
.70^{\star \star} \\
.48^{\star} \\
.38^{*}\end{array}$ & $\begin{array}{l}.24 \\
.17 \\
.17 \\
.19 \\
.17\end{array}$ \\
\hline $\begin{array}{l}\text { Opleidingsrichting: } \\
\text { - BIK } \\
\text { - Econometrie } \\
\text { - AE } \\
\text { - IM } \\
\text { - BE } \\
\text { - FE } \\
\text { - Economie-overig }\end{array}$ & $\begin{array}{l}1.13 \\
.06 \\
\text { referentie } \\
-1.01^{*} \\
.20 \\
.40 \\
-.70\end{array}$ & $\begin{array}{l}.67 \\
.36 \\
.42 \\
.28 \\
.54 \\
.41\end{array}$ \\
\hline $\mathrm{N}$ maanden afgestudeerd & .01 & .02 \\
\hline $\begin{array}{lc}\text {-2 Log Likelihood } & 965.4 \\
\text { Likelihood Ratio } & 93.3^{\star \star} \\
\mathrm{N} \text { cases } & 1026\end{array}$ & $\begin{array}{ll}\text { * } & \text { Significant op } \\
\text { ** } & \text { Significant op }\end{array}$ & $\begin{array}{l}5 \% \\
1 \%\end{array}$ \\
\hline
\end{tabular}

Op basis van de hiervoor genoemde veronderstellingen en de wijze waarop de variabelen zijn geoperationaliseerd, worden positieve effecten verwacht voor geslacht en voor de extra kwalificaties waarover men eventueel beschikt. Voor leeftijd wordt een negatief teken verwacht.

In de analyse, waarvan de resultaten in tabel 2.3 staan vermeld, komt naar voren dat de kans om snel werk te vinden niet significant wordt beïnvloed door het geslacht noch door het aantal maanden dat men reeds is afgestudeerd. Zoals eerder vermeld, is de laatstgenoemde variabele opgenomen om te corrigeren voor ongelijke perioden van arbeidsmarktintrede. 
De kans om snel werk te vinden is wel afhankelijk van de leeftijd en de additionele kwalificaties waarover men eventueel beschikt. Zoals verwacht, vinden jongere afgestudeerden sneller werk dan oudere afgestudeerden. Eveneens conform de verwachting komt naar voren dat afgestudeerden die beschikken over extra kwalificaties makkelijker werk vinden. Zo blijkt dat stage-ervaring, werkervaring en bestuurlijke ervaring de kans vergroten om snel werk te vinden. Hetzelfde geldt wanneer men beschikt over een hoger onderwijsdiploma voordat men economie gaat studeren. Tot slot komt naar voren dat afgestudeerden IM het langst naar werk zoeken.

\subsection{Verder onderwijs na afstuderen}

Deze paragraaf gaat in op het eventueel verder volgen van (regulier) onderwijs na het afstuderen (cursorisch onderwijs en bedrijfsopleidingen komen in hoofdstuk 4 aan bod). Eerst wordt een indicatie gegeven van de omvang van de deelname aan verder onderwijs. Tevens wordt aangegeven om welke onderwijsniveaus het hierbij gaat. Indien men meerdere opleidingen volgt of heeft gevolgd, gaat het bij het onderwijsniveau om de opleiding met het grootste aantal studie-uren. Tot slot komt het oordeel van de afgestudeerden over de aansluiting tussen de gevolgde opleiding en het verder gevolgd onderwijs aan bod.

\section{Deelname aan verder onderwijs}

Tabel 2.4 laat zien dat één op iedere vijf afgestudeerden (21\%) na het afstuderen gedurende kortere of langere tijd heeft deelgenomen aan verder onderwijs. Dit is iets meer dan de $18 \%$ bij de vorige enquête. Het gaat hierbij vrijwel steeds om opleidingen op academisch niveau. Afgestudeerden IM en FE volgen minder vaak verder onderwijs dan andere afgestudeerden. De meerderheid (83\%) van de afgestudeerden die verder onderwijs zijn gaan volgen, waren hiermee nog bezig op het moment van de enquête. Overigens wordt de deelname aan verder onderwijs doorgaans gecombineerd met betaald werk als belangrijkste bezigheid. Op het moment van de enquête heeft 'slechts' $1 \%$ studie als belangrijkste bezigheid.

Voor algemeen economen en afgestudeerden IM zijn AIO-/OIO-opleidingen economie de belangrijkste vervolgopleidingen. Voor afgestudeerden BIK, BE en Ec-overig is dit de postdoctorale beroepsopleiding accountancy en voor econometristen de $1 \mathrm{e}$ fase-opleiding actuariële wetenschappen. Het door fiscaal economen verder gevolgd onderwijs is gelijk verdeeld over de $1 e$ fase-opleiding bestuurskunde, de 1e faseopleiding recht en de postdoctorale beroepsopleiding accountancy. 


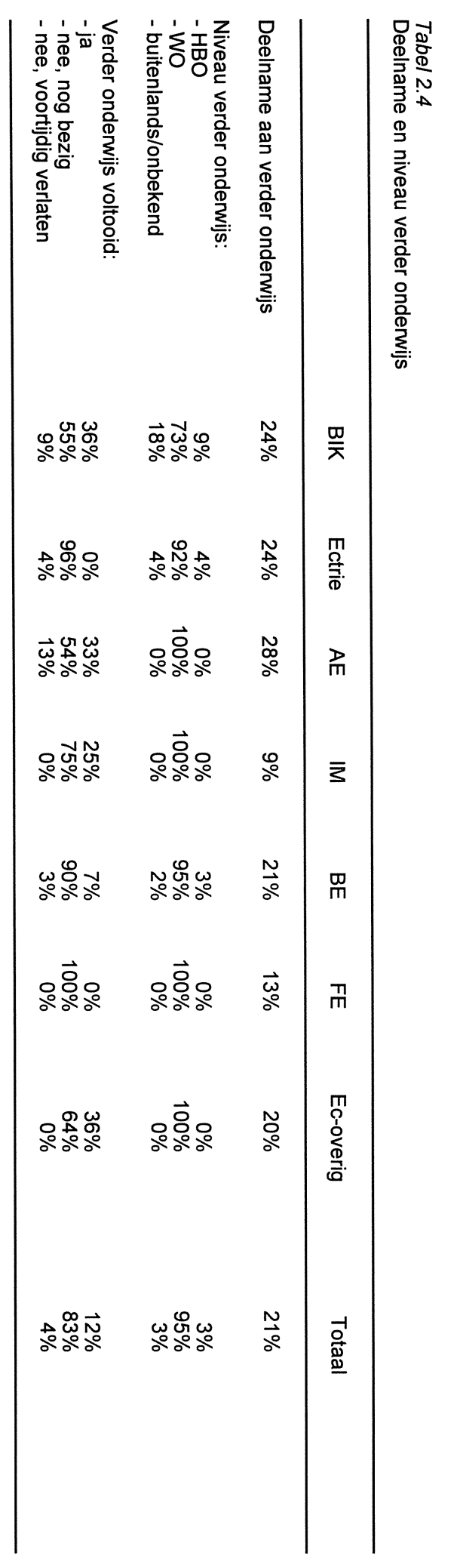


Oordeel over de aansluiting tussen gevolgde opleiding en verder onderwijs

Tot slot is aan de afgestudeerde economen gevraagd of zij tevreden zijn over de aansluiting tussen de gevolgde opleiding en het verder gevolgde onderwijs. Welnu, vrijwel alle (96\%) afgestudeerden die gedurende kortere of langere tijd verder onderwijs volgen, vindt de aansluiting voldoende of goed. Bij de vorige enquête was dit $93 \%$. 



\section{Functiekenmerken}

\subsection{Functieverwerving}

In dit hoofdstuk komen de betaalde functies van economen aan bod. Het gaat hierbij om afgestudeerden die op het moment van enquêteren, dus circa anderhalf jaar na afstuderen, in totaal tenminste 12 uur per week betaald werken. In het geval dat iemand meerdere betaalde functies heeft, hebben de gegevens betrekking op de functie met het grootste aantal arbeidsuren. Voordat de kenmerken van de baan aan bod komen, wordt eerst nagegaan op welke wijze men de baan heeft verkregen. Vervolgens wordt de werkkring getypeerd waarbinnen de functie wordt uitgeoefend en wordt aangegeven in welke beroepsklassen economen werkzaam zijn. Daarna komen de eisen aan bod die door de werkgever voor de vervulling van de functie worden gesteld, gevolgd door enkele arbeidsvoorwaarden.

Tabel 3.1 laat zien dat reageren op een advertentie (26\%) en ongevraagd solliciteren $(23 \%)$ de twee belangrijkste kanalen zijn waarmee pas afgestudeerde economen werk vinden. Eén op iedere acht afgestudeerden krijgt werk via een uitzendbureau $(12 \%)$ en een op de tien afgestudeerden via familie, vrienden of kennissen $(11 \%)$ danwel via stage of stagecontacten (11\%). Slechts $2 \%$ vindt werk via het Arbeidsbureau. In de vorige enquête kwam eveneens naar voren dat reageren op een advertentie $(26 \%)$ en ongevraagd solliciteren $(18 \%)$ de twee belangrijkste kanalen zijn waarmee pas afgestudeerden economen werk vinden. Uit het gestegen aandeel van ongevraagd solliciteren, van $18 \%$ vorig jaar naar $23 \%$ dit jaar, kan worden afgeleid dat economen zich bij het zoeken naar werk aktiever zijn gaan opstellen.

Met betrekking tot sommige kanalen waarmee men werk heeft gevonden, manifesteren zich duidelijke verschillen tussen de opleidingen. Voor econometristen en afgestudeerden BIK zijn stages van meer dan gemiddeld belang. Algemeen economen vinden vaker dan gemiddeld werk via advertenties en docenten. Fiscaal economen vinden niet alleen vaak werk via advertenties, maar worden ook relatief vaak door werkgevers gevraagd, bijvoorbeeld op banenmarkten of open dagen. Afgestudeerden IM vinden vaker dan gemiddeld een baan via advertenties en uitzendbureaus. Open sollicitaties zijn relatief belangrijk voor afgestudeerden van de overige economische opleidingen.

\subsection{Werkorganisatie}

In deze paragraaf worden de organisaties waarin de afgestudeerden op het moment van enquêteren werken eerst getypeerd naar personeelsomvang en bedrijfssector. Vervolgens wordt nagegaan of men heeft moeten verhuizen van de provincie waar men heeft gestudeerd naar de provincie waar men ten tijde van de enquête werkt 


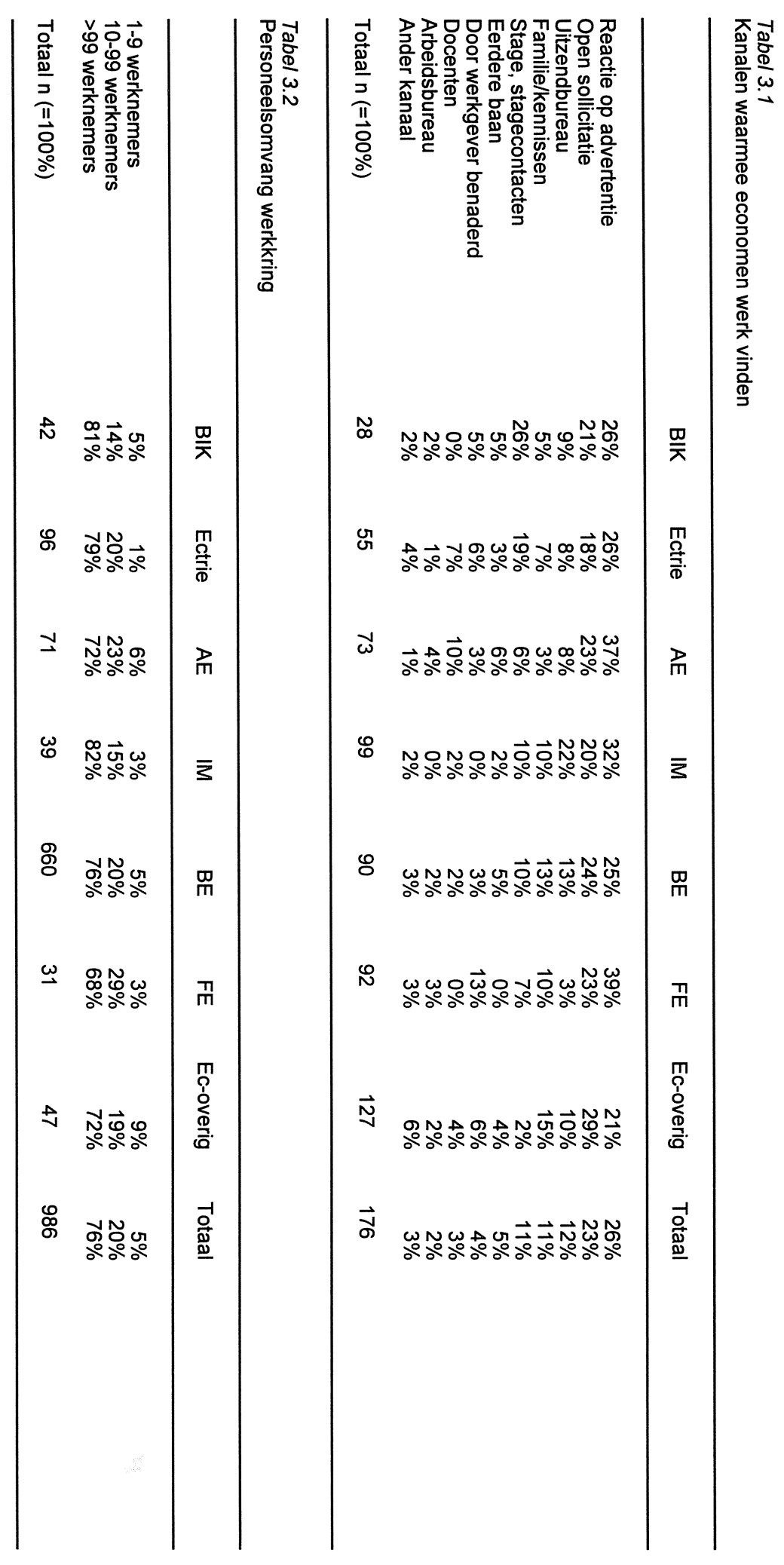


(geografische mobiliteit) en of men na het afstuderen al eens van werkorganisatie is veranderd (externe arbeidsmarktmobiliteit).

\section{Bedrijfsomvang}

Tabel 3.2 typeert de werkgelegenheid van economen naar de grootte van het bedrijf of de organisatie waar men werkt. Het gaat daarbij om het aantal werknemers bij het gehele concern.

Driekwart $(76 \%)$ van de economen werkt in grote organisaties, dat wil zeggen in bedrijven of instellingen met minimaal 100 werknemers. Eén op de vijf $(20 \%)$ is werkzaam in een middelgrote organisatie (10 tot 100 werknemers), terwijl $5 \%$ terecht komt in organisaties met maximaal 9 werknemers. In de vorige enquête was dit respectievelijk $71 \%, 22 \%$ en $8 \%$. Van alle afgestudeerden werken oudstudenten IM het vaakst in grote organisaties, fiscaal economen in middelgrote organisaties en afgestudeerden van de categorie overige opleidingen in kleine organisaties.

\section{Marktsector}

Tabel 3.3A geeft een beeld van de bedrijfsklassen waarin afgestudeerde economen terechtkomen. In deze tabel zijn alleen bedrijfsklassen opgenomen waarin tenminste $5 \%$ van de betaald-werkende afgestudeerden van de desbetreffende opleiding werkzaam is.

Tabel 3.3B geeft per opleiding een overzicht van de belangrijkste beroepen van de betaald-werkende afgestudeerden. Hierbij worden alleen de beroepen vermeld waarin tenminste $5 \%$ van de betaald-werkende afgestudeerden van de desbetreffende opleiding werken.

\section{Geografische mobiliteit}

Geografische mobiliteit duidt op de bereidheid van afgestudeerden om voor een baan te verhuizen of te pendelen. Daarnaast zegt geografische mobiliteit iets over de werkgelegenheidssituatie in de eigen regio: bij onvoldoende geschikte banen in de eigen regio zijn afgestudeerden namelijk genoodzaakt om banen verder van huis te accepteren. Met eigen regio wordt hier bedoeld de provincie waar men heeft gestudeerd of een daaraan grenzende provincie. 
Tabel 3.3A

Belangrijkste bedrijfsklassen

Afgestudeerden BIK:

$\begin{array}{ll}\text { - adviesbureaus automatisering, systeeemhuizen } & 21 \% \\ \text { - groothandel computers/kantoormachines-meubels } & 12 \%\end{array}$

- computerservice-/informatie- technologiebureaus $\quad 12 \%$

- accountant/boekhoudbureaus $\quad 9 \%$

- geldscheppende financiële instellingen $7 \%$

$\begin{array}{ll}\text { - systeemontwikkelings-/systeemanalyse-/programmeerdienstvelening } & 5 \% \\ \text { - politie } & 5 \%\end{array}$

Afgestudeerden Econometrie:

- hoger onderwijs

- schadeverzekeringen

$12 \%$

- geldscheppende financiële instellingen $10 \%$

- economisch onderzoeks-/adviesbureaus $\quad 8 \%$

- groothandel computers/kantoormachines-meubels $\quad 7 \%$

Afgestudeerden AE:

- geldscheppende financiële instellingen $\quad 21 \%$

- algemeen overheidsbestuur $\quad 14 \%$

- hoger onderwijs $11 \%$

$\begin{array}{lr}\text { - economisch onderzoeks-/adviesbureaus } & 10 \% \\ \text { - uitzend-/arbeidsbemiddelingsbureaus } & 6 \%\end{array}$

Afgestudeerden IM:

- vervaardiging (petro)chemische produkten $\quad 10 \%$

- verwerking tabak

- reklamebureaus e.d.

- uitzend-/arbeidsbemiddelingsbureaus $\quad 5 \%$

- defensie

- hoger onderwijs

Afgestudeerden BE:

- accountant/boekhoudbureaus $\quad 13 \%$

- geldscheppende financiële instellingen $12 \%$

- economische onderzoeks-/adviesbureaus $\quad 6 \%$

- groothandel computers/kantoormachines-meubels $\quad 5 \%$

Afgestudeerden FE:

- accountant/boekhoudbureaus $\quad 58 \%$

- algemeen overheidsbestuur $16 \%$

Afgestudeerden Ec-overig:

- adviesbureaus automatisering, systeeemhuizen $\quad 10 \%$

- economische onderzoeks-/adviesbureaus $10 \%$

- algemeen overheidsbestuur 
Tabel 3.3.B

Belangrijkste beroepen

Afgestudeerden BIK

- systeemanalist/-ontwerper

- projectadviseur automatisering

- programmeur (wetenschappelijke toepassingen)

- systeem-/netwerkbeheerder

- assistent-accountant, administrateur (HBO-niveau)

- automatiseringsadviseur

- systeemprogrammeur (wetenschappelijke toepassingen)

- bedrijfsorganisatiedeskundige

Afgestudeerden Econometrie:

- systeemanalist/-ontwerper

- wetenschappelijk onderzoeker bedrijfs-/algemene economie

- actuaris

-beleggings-/krediet-/financieel adviseur; kredietanalist

- bedrijfsorganisatiedeskundige

- wetenschappelijk onderzoeker econometrie/actuariaat

Afgestudeerden AE:

- wetenschappelijk onderzoeker bedrijfs-/algemene economie $\quad 12 \%$

- docent WO

- beleggings-/krediet-/financieel adviseur; kredietanalist

- (bedrijfs)econoom (excl. wetenschappelijk onderzoek)

- beleidsmedewerker economische zaken

- bedrijfsorganisatiedeskundige

- wetenschappelijk onderzoeker marketing

Afgestudeerden IM:

- hoofd/salesmanager kleine/middelgrote afdeling verkoop

- marketingadviseur/-specialist

- wetenschappelijk onderzoeker bedrijfs-/algemene economie

- administratief medewerker arbeidsbemiddeling;

personeelsfunctionaris

- marketing-onderzoeker

- groothandelaar; effectenarbitrageant

- hoofd kleine afdeling export

- coördinator/consulent onderwijs

- boekhouder (wetenschappelijk)

- accountant

- wetenschappelijk onderzoeker marketing

Afgestudeerden BE:

- assistent-accountant, administrateur (HBO-niveau)

- beleggings-/krediet-/financieel adviseur; kredietanalist

- accountant

- bedrijfsorganisatiedeskundige

- wetenschappelijk onderzoeker marketing

Afgestudeerden FE:

- belastingconsulent (wetenschappelijk)

- assistent-accountant, administrateur (HBO-niveau)

- inspecteur belastingen

Afgestudeerden Ec-overig:

- marketingadviseur/-specialist

- logistiek organisatie-assistent

- hoofd/salesmanager kleine/middelgrote afdeling verkoop

- bedrijfsorganisatiedeskundige 
In dit rapport is sprake van geografische mobiliteit wanneer men werkt in een provincie die niet grenst aan de provincie waar de universiteit is gesitueerd, of wanneer men in het buitenland werkt. Aldus opgevat, is een kwart $(23 \%)$ van de betaald-werkende economen geografisch mobiel. Vorig jaar was dit $16 \%$. De geografische mobiliteit is dus fors toegenomen. Tabel 3.4 laat zien dat van alle afgestudeerden oudstudenten BIK het vaakst buiten de eigen regio gaan werken. Oudstudenten IM werken vaker dan gemiddeld in het buitenland.

\section{Externe arbeidsmarktmobiliteit}

In de enquête is gevraagd bij hoeveel organisaties men na het afstuderen heeft gewerkt gedurende tenminste 12 uur per week (excl. militaire of vervangende dienst, doch incl. de huidige werkgever of een eventueel eigen bedrijf). Uitzendperiodes moesten hierbij ieder afzonderlijk worden meegeteld. Welnu, zo'n anderhalf jaar na het afstuderen is $44 \%$ (vorig meetjaar $41 \%$ ) van de betaald-werkende respondenten niet langer in hun eerste werkkring werkzaam: zij zijn na het afstuderen al eens van werkkring veranderd. Afgestudeerden Ec-overig (60\%), AE (46\%), IM (45\%) en $\mathrm{BE}$ (45\%) zijn vaker dan gemiddeld al eens van werkkring veranderd, terwijl afgestudeerden BIK (37\%), Econometrie (34\%) en FE (24\%) minder vaak dan gemiddeld van werkkring zijn veranderd.

\subsection{Functievereisten}

In deze paragraaf wordt ingegaan op de eisen die door de werkgevers zijn gesteld bij de werving en selectie voor de functies die de afgestudeerden op het enquêtemoment vervullen. Daarbij komt eerst de vereiste opleidingsrichting en het vereiste opleidingsniveau aan bod. Vervolgens wordt ingegaan op de vraag of werkervaring werd vereist voor de functie. Tot slot wordt nagegaan of het een leidinggevende functie betreft.

\section{Vereiste opleidingsrichting}

De opleidingsrichting die door de werkgever voor de vervulling van de functie werd vereist, geeft aan of de afgestudeerde al dan niet binnen het 'eigen' beroependomein terecht komt. Van het 'eigen' beroependomein is sprake wanneer voor de desbetreffende functie (uitsluitend) de eigen opleidingsrichting of een daaraan verwante opleidingsrichting werd vereist. Buiten het eigen beroependomein is sprake van concurrentie door afgestudeerden van andere opleidingsrichtingen. Dit is het geval wanneer voor de desbetreffende functie geen specifieke opleidingsrichting of een geheel andere dan de eigen opleidingsrichting werd vereist. 


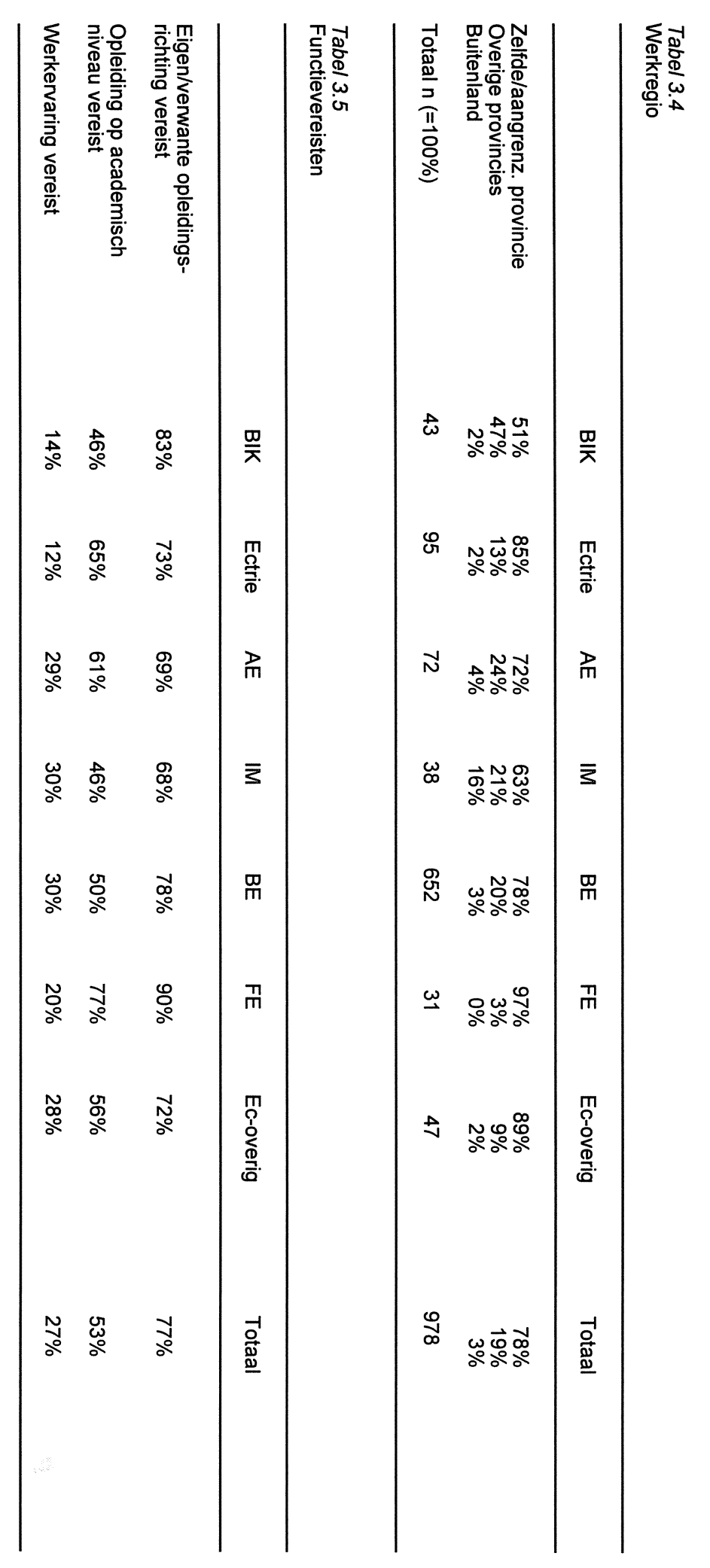


Tabel 3.5 geeft aan hoeveel procent van de betaald-werkende afgestudeerden binnen het eigen beroependomein werkt. Naar voren komt dat de meeste economen (77\%) functies uitoefenen die passen bij hun opleidingsrichting (bij de vorige meting was dit $80 \%$ ). Van alle afgestudeerden zijn oudstudenten FE het vaakst binnen het eigen domein werkzaam.

\section{Vereist opleidingsniveau}

Naast de vereiste opleidingsrichting is in de enquête gevraagd naar het opleidingsniveau dat door de werkgever voor de vervulling van de functie werd vereist. Wat het minimaal vereiste opleidingsniveau betreft, kan een hoofdonderscheid worden gemaakt tussen functies waarvoor een opleiding op academisch niveau niet is vereist en functies waarvoor men een academische opleiding moet hebben gevolgd. Wanneer een academische opleiding niet is vereist voor de vervulde functie is er sprake van potentiële onderbenutting van capaciteiten bij de uitoefening van de functie. Hierbij mag evenwel niet worden vergeten dat het gaat om startfuncties, waarbij doorgroei mogelijk is naar een niveau dat beter aansluit bij de gevolgde opleiding. Dit laat echter onverlet dat een hoog onderbenuttingspercentage wijst op een slechte marktpositie voor de desbetreffende opleiding, zeker in combinatie met een lage kans op werk.

De resultaten met betrekking tot het vereiste opleidingsniveau zijn weergegeven in tabel 3.5. De tabel laat zien dat slechts iets meer dan de helft (53\%) van de betaaldwerkende afgestudeerden een functie op academisch niveau heeft (fiscaal economen komen het vaakst terecht in functies op academisch niveau). Dit betekent dat bijna de helft werkzaam is in functies die ook door opgeleiden op een lager niveau, bijvoorbeeld HBO'ers, kunnen worden vervuld. Hierbij kan een rol spelen dat de academische economische opleidingen pendantopleidingen op een lager niveau hebben, namelijk in het HEAO. Zo blijkt onder afgestudeerden van gezondheidswetenschappen van de UM, opleidingen met eveneens pendantopleidingen op een lager niveau, maar liefst $64 \%$ een functie te hebben die ook door nietacademisch opgeleiden kan worden vervuld. Ter vergelijking: bij afgestudeerden geneeskunde en rechtsgeleerdheid van de UM, twee academische opleidingen zonder pendantopleidingen op een lager niveau, is respectievelijk slechts $1 \%$ en $28 \%$ werkzaam in functies die ook door niet-academisch opgeleiden kunnen worden vervuld.

Bij de vorige meting onder economen was $61 \%$ in een functie op academisch niveau werkzaam. Dit betekent dat de potentiële onderbenutting van kwalificaties sterk is toegenomen. Ter vergelijking: in de in 1995 uitgevoerde meting onder afgestudeerden van het hoger beroepsonderwijs, de HBO-Monitor 1995, is gebleken dat $75 \%$ van de HEAO'ers een functie op HBO-niveau heeft (bij de vorige meting was dit $74 \%)$. 
Hieronder wordt nagegaan welke factoren van invloed zijn op de kans om terecht te komen in banen die passen bij de gevolgde opleiding. Om deze vraag te kunnen beantwoorden, is eerst de kans geschat dat voor de baan de eigen opleidingsrichting of een daaraan verwante opleidingsrichting is vereist. Daarnaast is de kans geschat dat de baan wat het vereiste opleidingsniveau betreft, past bij de genoten opleiding. De resultaten van beide schattingen staan vermeld in tabel 3.6.

Tabel 3.6

Logistische regressie-analyse van de kans dat het werk past bij de richting en het niveau van de gevolgde opleiding

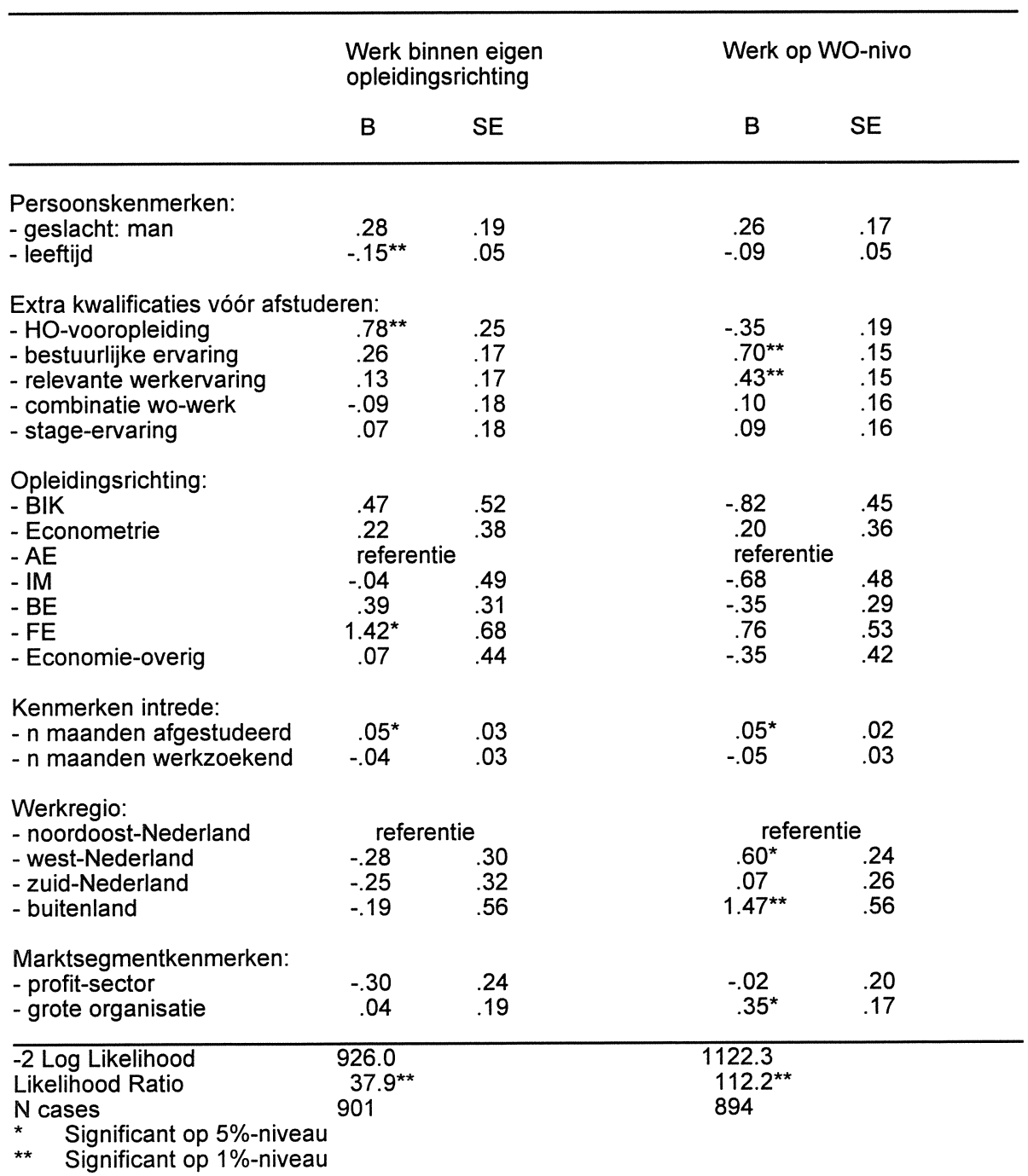


In beide schattingen zijn dezelfde variabelen gebruikt voor het operationaliseren van de persoonskenmerken, de gevolgde opleiding en de extra kwalificaties waarover men eventueel beschikt als eerder het geval is geweest bij de analyse van de kans om snel werk te vinden. Voor het soort werkorganisatie zijn twee dummy-variabelen in de analyse opgenomen, namelijk het werken in een profit-organisatie (profitsector) en het werken in organisatie met meer dan 100 werknemers (grote organisatie). Met eventuele regionale verschillen in de werkgelegenheidssituatie is in de analyse rekening gehouden door het opnemen van de variabele werkregio (noordoost-Nederland, west-Nederland, zuid-Nederland en het buitenland). De wijze waarop de arbeidsmarktintrede is verlopen, wordt geoperationaliseerd door het aantal maanden dat men werkzoekend is geweest.

Voor alle verklarende variabelen zijn dummies geconstrueerd, behoudens voor de leeftijd in jaren (leeftijd), het aantal maanden dat men na het afstuderen werkzoekend is geweest ( $n$ maanden werkzoekend) en het aantal maanden dat men reeds is afgestudeerd ( $n$ maanden afgestudeerd). Om te voorkomen dat extreme waarden een te zware wissel zouden trekken op de analyseresultaten, is ook in deze analyses de leeftijd van dertigplussers op 31 jaar gesteld. Voor de preciese omschrijving van de verklarende variabelen wordt verwezen naar bijlage 1 . In de schattingen fungeerde $A E$ als referentie voor de gevolgde opleiding en het noordoosten van Nederland (noordoost-Nederland) als referentie voor de werkregio.

Zoals gezegd, is eerst de kans geschat dat voor de functie de eigen of een verwante opleidingsrichting is vereist. Als referentiecategorie zijn functies genomen waarvoor geen specifieke, of een geheel andere opleidingsrichting is vereist.

De schattingsresultaten in tabel 3.6 laten zien dat de kans op werk in de eigen opleidingsrichting niet afhangt van de regio en het marktsegment waarin men terecht komt. Deze kans hangt wel samen met de leeftijd, de genoten vooropleiding, de gevolgde opleiding en het aantal maanden dat men reeds is afgestudeerd. In de analyse komt naar voren dat oudere afgestudeerden minder vaak binnen de eigen opleidingsrichtingen van economen werkzaam zijn dan jongere afgestudeerden. Een mogelijke verklaring hiervoor, namelijk dat ouderen vaker de studie hebben gecombineerd met een betaalde baan buiten het eigen domein van economen waarin zij na het afstuderen veelal zijn blijven werken, gaat niet op omdat hiervoor in de analyse is gecorrigeerd.

Extra menselijk kapitaal in de vorm van het reeds beschikken over een hoger onderwijsdiploma alvorens economie te gaan studeren, vergroot de kans om later werk te vinden in het eigen beroependomein van economen. Deze kans neemt ook toe naarmate de periode na afstuderen langer is en men dus meer tijd heeft gehad om passend werk te verwerven, al dan niet in een eventueel tweede baan na afstuderen. 
Met betrekking tot het effect van de gevolgde opleiding blijkt dat fiscaal economen de grootste kans hebben om in het eigen beroependomein terecht te komen.

\section{Schatting van de kans op een WO-niveau functie}

Daarnaast is de kans geschat dat voor de functie een opleiding op academisch niveau is vereist. Als referentiegroep voor degenen die op hun niveau werken, fungeerden de oudstudenten die onder hun opleidingsniveau werken. De schattingsresultaten in tabel 3.6 laten zien dat de opgenomen persoonskenmerken en de gevolgde opleiding geen significante rol spelen bij de kans om werk te krijgen dat past bij het niveau van de genoten opleiding. Deze kans wordt wel beïnvloed door de extra kwalificaties waarover men eventueel beschikt, het aantal maanden dat men reeds is afgestudeerd, de grootte van de werkorganisatie waarin afgestudeerden terechtkomen en de regio waar zij werkzaam zijn.

Extra menselijk kapitaal in de vorm van bestuurlijke ervaring en voor het vakgebied relevante werkervaring, opgedaan vóór of tijdens de opleiding, vergroten de kans om later werk te krijgen op academisch niveau. Deze kans neemt ook toe naarmate de periode na het afstuderen langer is en men dus meer tijd heeft gehad om werk op academisch niveau te verwerven, al dan niet in een eventueel tweede baan na het afstuderen.

In de analyse komt verder naar voren dat de kans op werk dat past bij het niveau van de genoten opleiding groter is wanneer men in het westen des lands of in het buitenland werkzaam is. Hetzelfde geldt wanneer men in een grote organisatie werkt.

\section{Vereiste werkervaring}

Het laatste aspect met betrekking tot de eisen die door de werkgever bij de werving en selectie zijn gesteld, betreft het al dan niet vereist zijn van werkervaring. Tabel 3.5 laat zien dat één op de vier afgestudeerden $(27 \%)$ aangeeft dat voor de functie werkervaring werd vereist (bij de vorige meting was dit $30 \%$ ). Het geringe aandeel van banen waarvoor werkervaring werd vereist, is niet verwonderlijk aangezien het gaat om intreders op de arbeidsmarkt. Tabel 3.5 laat verder zien dat het percentage werkenden met een baan waarvoor werkervaring werd vereist het laagst is onder econometristen.

\section{Leidinggeven}

In de enquête is gevraagd of men een leidinggevende functie heeft en, zo ja, aan hoeveel mensen men leiding geeft. Het antwoord op deze vraag geeft een indicatie van de mate waarin men leiding geeft, variërend van 'geen leidinggevende functie' 
tot 'leiding aan 50 of meer personen'. De antwoorden op deze vraag geven evenwel geen beeld van het niveau waarop leiding wordt gegeven, dit wil zeggen van de opleidingsniveaus van de mensen waaraan men leiding geeft.

Gebleken is dat $21 \%$ (vorig meetjaar $23 \%$ ) van de betaald-werkende afgestudeerden in leidinggevende functies werkzaam is. Dit is niet verwonderlijk omdat deze populatie nog aan het begin van de beroepscarrière staat. Het percentage leidinggevenden is het hoogst onder oudstudenten IM (34\%) en het laagst onder econometristen (12\%). Bij de andere opleidingen varieert het aandeel van leidinggevenden van $14 \%$ bij $A E, 19 \%$ bij BIK, $22 \%$ bij BE en $23 \%$ bij Ec-over tot $26 \%$ bij FE.

Tabel 3.7

Logistische regressie-analyse van de kans op een leidinggevende functie

\begin{tabular}{|c|c|c|}
\hline & B & SE \\
\hline $\begin{array}{l}\text { Persoonskenmerken: } \\
\text { - geslacht: man } \\
\text { - leeftijd }\end{array}$ & $\begin{array}{l}.35 \\
.23^{\star \star}\end{array}$ & $\begin{array}{l}.23 \\
.05\end{array}$ \\
\hline $\begin{array}{l}\text { Extra kwalificaties vóór afstuderen: } \\
\text { - HO-vooropleiding } \\
\text { - bestuurlijke ervaring } \\
\text { - relevante werkervaring } \\
\text { - combinatie wo-werk } \\
\text { - stage-ervaring }\end{array}$ & $\begin{array}{l}.16 \\
.44^{*} \\
.41^{*} \\
.12 \\
-.17\end{array}$ & $\begin{array}{l}.23 \\
.19 \\
.20 \\
.20 \\
.20\end{array}$ \\
\hline $\begin{array}{l}\text { Opleidingsrichting: } \\
\text { - BIK } \\
\text { - Econometrie } \\
\text { - AE } \\
\text { - IM } \\
\text { - BE } \\
\text { - FE } \\
\text { - Economie-overig }\end{array}$ & $\begin{array}{l}.25 \\
.11 \\
\text { referentie } \\
1.02 \\
.29 \\
.54 \\
.24\end{array}$ & $\begin{array}{l}.58 \\
.50 \\
.56 \\
.39 \\
.57 \\
.55\end{array}$ \\
\hline $\begin{array}{l}\text { Kenmerken intrede: } \\
\text { - } \mathrm{n} \text { maanden afgestudeerd } \\
\text { - } \mathrm{n} \text { maanden werkzoekend }\end{array}$ & $\begin{array}{l}.02 \\
-.24^{\star \star}\end{array}$ & $\begin{array}{l}.03 \\
.05\end{array}$ \\
\hline $\begin{array}{l}\text { Werkregio: } \\
\text { - noordoost-Nederland } \\
\text { - west-Nederland } \\
\text { - zuid-Nederland } \\
\text { - buitenland }\end{array}$ & $\begin{array}{l}\text { referentie } \\
-.41 \\
.21 \\
-.35\end{array}$ & $\begin{array}{l}.29 \\
.31 \\
.59\end{array}$ \\
\hline $\begin{array}{l}\text { Marktsegmentkenmerken: } \\
\text { - profit-sector } \\
\text { - grote organisatie }\end{array}$ & $\begin{array}{l}.10 \\
-.69^{\star \star}\end{array}$ & $\begin{array}{l}.26 \\
.19\end{array}$ \\
\hline $\begin{array}{l}-2 \text { Log Likelihood } \\
\text { Likelihood Ratio } \\
\text { N cases }\end{array}$ & $\begin{array}{ll}* & \text { Significant op 5\%- } \\
* * & \text { Significant op 1\%- }\end{array}$ & $\begin{array}{l}\text { niveau } \\
\text { niveau }\end{array}$ \\
\hline
\end{tabular}




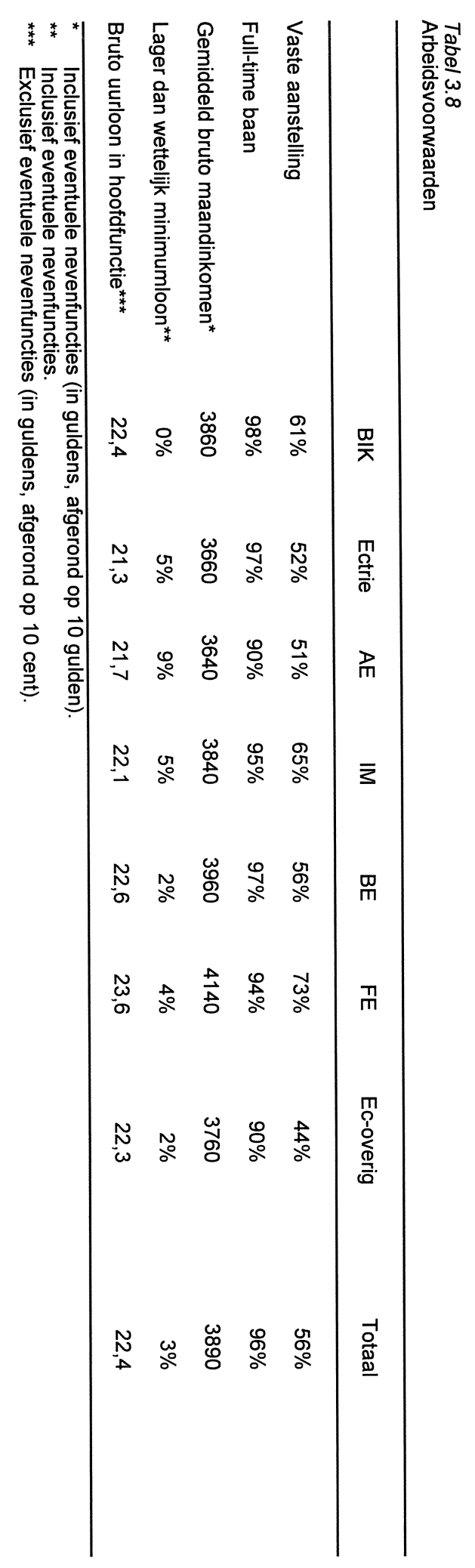




\section{Schatting van de kans op een leidinggevende functie}

Er is nagegaan welke factoren van invloed zijn op het al dan niet hebben van een leidinggevende functie. In de logistische regressie-analyse van de kans op een leidinggevende functie zijn dezelfde verklarende variabelen en dezelfde referentiecategorieën gebruikt als eerder bij de analyses van de kans op werk dat past bij de richting en het niveau van de gevolde opleiding. Voor de preciese omschrijving van de verklarende variabelen wordt verwezen naar bijlage 1.

De analyseresultaten in tabel 3.7 laten zien dat de kans op een leidinggevende functie niet significant wordt beïnvloed door het geslacht noch door de gevolgde opleiding. Evenmin spelen eventuele regionale verschillen hierbij een rol.

De kans op een leidinggevende functie blijkt wel samen te hangen met de leeftijd, de eventuele extra kwalificaties waarover men beschikt, het verloop van de arbeidsmarktintrede en de groottte van het bedrijf waarin men terecht komt. Zo blijkt de kans op een leidinggevende functie toe te nemen met de leeftijd. Deze kans is ook groter wanneeer men beschikt over bestuurlijke ervaring en voor het vakgebied relevante werkervaring. De kans op een leidinggevende functie daalt daarentegen naarmate men langer werkzoekend is geweest en wanneer men in een grote organisatie terechtkomt.

\subsection{Arbeidsvoorwaarden}

In deze paragraaf over de arbeidsvoorwaarden van de economen komen eerst het soort dienstverband, de duur van de aanstelling en de wekelijkse arbeidsduur aan bod. Vervolgens wordt ingegaan op de hoogte van het inkomen.

\section{Dienstverband en aanstellingsduur}

Van de betaald-werkende respondenten werkt $89 \%$ in loondienst bij een werkgever en $7 \%$ via een uitzendbureau. Slechts $2 \%$ werkt als zelfstandige in een eigen bedrijf danwel freelance. De overige $2 \%$ werkt als oproepkracht (0-uren contract of $\mathrm{min} / \mathrm{max}$ contract), via een werkervaringsproject of als meewerkend gezinslid met arbeidscontract in het bedrijf van de ouders/partner. Per saldo is $98 \%$ van alle betaald-werkende afgestudeerden op contractuele basis werkzaam (dus exclusief de zelfstandigen en freelancers).

Aan de betaald-werkende economen die op contractuele basis werken, is gevraagd wat de aard van hun aanstelling is. Tabel 3.8 toont de percentages met een vaste aanstelling. Geconstateerd kan worden dat circa anderhalf jaar na het afstuderen ruim de helft (56\%) al een vaste aanstelling heeft. Dit komt vrijwel overeen met vorig 
jaar (58\% vaste aanstellingen). Fiscaal economen en afgestudeerden IM en BIK hebben vaker dan gemiddeld een vaste aanstelling.

\section{Schatting van de kans op een vaste aanstelling}

Voor de afgestudeerden die op contractuele basis werken, is met behulp van logistische regressie-analyse nagegaan welke kenmerken een verklaring kunnen bieden voor het al dan niet krijgen van een vaste aanstelling.

Tabel 3.9

Logistische regressie-analyse van de kans op een vaste aanstelling

\begin{tabular}{|c|c|c|}
\hline & B & SE \\
\hline $\begin{array}{l}\text { Persoonskenmerken: } \\
\text { - geslacht: man } \\
\text { - leeftijd }\end{array}$ & $\begin{array}{l}-.08 \\
.20^{\star \star}\end{array}$ & $\begin{array}{l}.17 \\
.05\end{array}$ \\
\hline $\begin{array}{l}\text { Extra kwalificaties vóór afstuderen: } \\
\text { - HO-vooropleiding } \\
\text { - bestuurlijke ervaring } \\
\text { - relevante werkervaring } \\
\text { - combinatie wo-werk } \\
\text { - stage-ervaring }\end{array}$ & $\begin{array}{r}-.23 \\
.14 \\
.08 \\
-.04 \\
.02\end{array}$ & $\begin{array}{l}.20 \\
.16 \\
.16 \\
.17 \\
.17\end{array}$ \\
\hline $\begin{array}{l}\text { Opleidingsrichting: } \\
\text { - BIK } \\
\text { - Econometrie } \\
\text { - AE } \\
\text { - IM } \\
\text { - BE } \\
\text { - FE } \\
\text { - Economie-overig }\end{array}$ & $\begin{array}{l}.34 \\
-.01 \\
\text { referentie } \\
.86 \\
.02 \\
.79 \\
-.68\end{array}$ & $\begin{array}{l}.47 \\
.37 \\
\\
.51 \\
.30 \\
.54 \\
.43\end{array}$ \\
\hline $\begin{array}{l}\text { Kenmerken intrede: } \\
\text { - } \mathrm{n} \text { maanden afgestudeerd } \\
\text { - } \mathrm{n} \text { maanden werkzoekend }\end{array}$ & $\begin{array}{l}.08^{\star *} \\
-.19^{\star \star}\end{array}$ & $\begin{array}{l}.02 \\
.03\end{array}$ \\
\hline $\begin{array}{l}\text { Werkregio: } \\
\text { - noordoost-Nederland } \\
\text { - west-Nederland } \\
\text { - zuid-Nederland } \\
\text { - buitenland }\end{array}$ & $\begin{array}{l}\text { referentie } \\
.08 \\
-.76^{\star \star} \\
.48\end{array}$ & $\begin{array}{l}.25 \\
.27 \\
.51\end{array}$ \\
\hline $\begin{array}{l}\text { Marktsegmentkenmerken: } \\
\text { - profit-sector } \\
\text { - grote organisatie }\end{array}$ & $\begin{array}{l}1.16^{\star \star} \\
-.19\end{array}$ & $\begin{array}{l}.21 \\
.18\end{array}$ \\
\hline $\begin{array}{l}-2 \text { Log Likelihood } \\
\text { Likelihood Ratio } \\
\mathrm{N} \text { cases }\end{array}$ & $\begin{array}{ll}* & \text { Significant } \\
* * & \text { Significant }\end{array}$ & op 5 \\
\hline
\end{tabular}

In de analyse van de kans op een vaste baan zijn dezelfde verklarende variabelen gebruikt als eerder het geval is geweest bij de schattingen van de vereiste oplei- 
dingsrichting, het vereiste opleidingsniveau en de kans op een leidinggevende functie. De resultaten van de analyse worden in tabel 3.9 weergegeven.

De analyseresultaten in tabel 3.9 laten zien dat de kans op een vaste baan niet significant wordt beïnvloed door het geslacht, de gevolgde opleiding, het eventuele extra menselijk kapitaal waarover afgestudeerden beschikken, noch door de grootte van de werkorganisatie waar men terecht komt.

De kans op een vaste baan blijkt wel afhankelijk te zijn van leeftijd, de wijze waarop de intrede op de arbeidsmark is verlopen alsmede de regio en marktsector waar men werkt. Zo blijken oudere afgestudeerden vaker in vaste dienst te werken dan jongeren. Dit hangt wellicht hiermee samen dat oudere afgestudeerden meer baanzekerheid zoeken dan jongeren. Een mogelijk andere verklaring, namelijk dat ouderen vaker de studie hebben gecombineerd met een betaalde baan waarin zij na het afstuderen veelal zijn blijven werken, gaat niet op. Immers voor het combineren van de WO-opleiding met werk is in de betreffende analyse al gecorrigeerd.

De kans op vast werk blijkt toe te nemen naarmate de periode na het afstuderen langer is en af te nemen naarmate men langer naar werk heeft moeten zoeken. In de analyse komt verder naar voren dat de kans op een vaste aanstelling mede verschilt naar regio: in de zuidelijke provincies is deze kans kleiner dan in noordoost-Nederland. De analyseresultaten laten tot slot zien dat men in (semi)overheidsdienst een kleinere kans op vast werk heeft dan in de profit-sector.

\section{Wekelijkse arbeidsduur}

Dit aspect van de arbeidsvoorwaarden geeft een indicatie van de mate van arbeidsparticipatie. Tabel 3.8 geeft aan hoeveel betaald-werkende afgestudeerden een fulltime baan hebben, dat wil zeggen een baan van minimaal 33 uur per week. Wanneer men meerdere banen heeft, wordt uitgegaan van de baan met het grootste aantal arbeidsuren. Tabel 3.8 laat zien dat vrijwel iedereen (96\%) in voltijd werkt en dat zich hierbij geen grote verschillen tussen de opleidingsrichtingen voordoen. Overigens bedroeg het aandeel van full-time banen bij de vorige meting 95\%. De mate van arbeidsparticipatie is dus nagenoeg gelijk gebleven.

$\mathrm{Er}$ is ook nagegaan of zich ten aanzien van dit baanaspect verschillen tussen mannen en vrouwen manifesteren. Dit blijkt niet het geval te zijn. Van de betaaldwerkende mannen heeft $96 \%$ een full-time baan; bij de vrouwen bedraagt het percentage eveneens 96 . 
Inkomen

Als laatste baankenmerk komt het inkomen aan bod, dat betaald-werkende economen zo'n anderhalf jaar na het afstuderen verdienen. Aansluitend bij de definitie die het CBS hanteert bij het jaarlijks onderzoek naar de verdiende lonen, is in de enquête achtereenvolgens voor de hoofdfunctie en eventuele nevenfunctie(s) gevraagd naar het bruto maandinkomen:

- inclusief eventuele toeslagen voor onregelmatig werk, ploegendienst, provisie en dergelijke;

- exclusief inkomsten uit overwerk en bijzondere uitkeringen zoals $13 \mathrm{e}$ maand, winstdeling, gratificatie, vakantiegeld, kinderbijslag, vergoeding voor reiskosten en kleding, en dergelijke.

Tabel 3.8 laat zien dat betaald-werkende economen zo'n anderhalf jaar na het afstuderen gemiddeld 3890 gulden bruto per maand verdienen. Dit is incl. eventuele nevenfunctie(s). Fiscaal economen verdienen gemiddeld het meest. Bij de vorige enquête bedroeg het gemiddeld bruto maandinkomen 3.930 gulden.

In tabel 3.8 is tevens vermeld hoeveel afgestudeerden minder verdienen dan het wettelijk minimum maandloon en daarmee in feite niet (structureel) in het eigen levensonderhoud kunnen voorzien. Het wettelijk vastgestelde minimumloon is afhankelijk van de leeftijd en bedraagt voor iemand van tenminste 23 jaar 2180 gulden bruto per maand. De tabel laat zien dat $3 \%$ van de betaald-werkende afgestudeerden een inkomen uit arbeid beneden dit minimumloon heeft. Dit varieert van $0 \%$ bij afgestudeerden BIK tot $9 \%$ bij afgestudeerden $A E$. Hierbij kunnen echter verschillen in de lengte van de werkweek een rol spelen. Om de inkomens hiervoor te corrigeren zijn eveneens de bruto uurlonen berekend (incl. toeslagen, doch excl. nevenfuncties). Per uur verdienen betaald-werkende afgestudeerden gemiddeld 22,40 gulden bruto in hun hoofdfunctie. Dit betekent een lichte daling ten opzichte van de 23,30 gulden in de vorige enquête. Fiscaal economen verdienen per uur gemiddeld het meest en econometristen het minst (tabel 3.8).

\section{Schatting van de hoogte van het inkomen}

Met behulp van lineaire regressie-analyse is gepoogd om na te gaan welke kenmerken van invloed zijn op de hoogte van het bruto uurloon van de betaald-werkende afgestudeerden. Het bruto uurloon (incl. toeslagen) is berekend voor de hoofdfunctie van de afgestudeerden, dus excl. de inkomsten uit eventuele nevenfuncties. Om te voorkomen dat extreem lage en hoge uurlonen te zwaar zouden doorwegen in de analyseresultaten, is het bruto uurloon in de analyse logarithmisch getransformeerd. 
Tabel 3.10

Lineaire regressie-analyse van het log. bruto uurloon in de hoofdfunctie

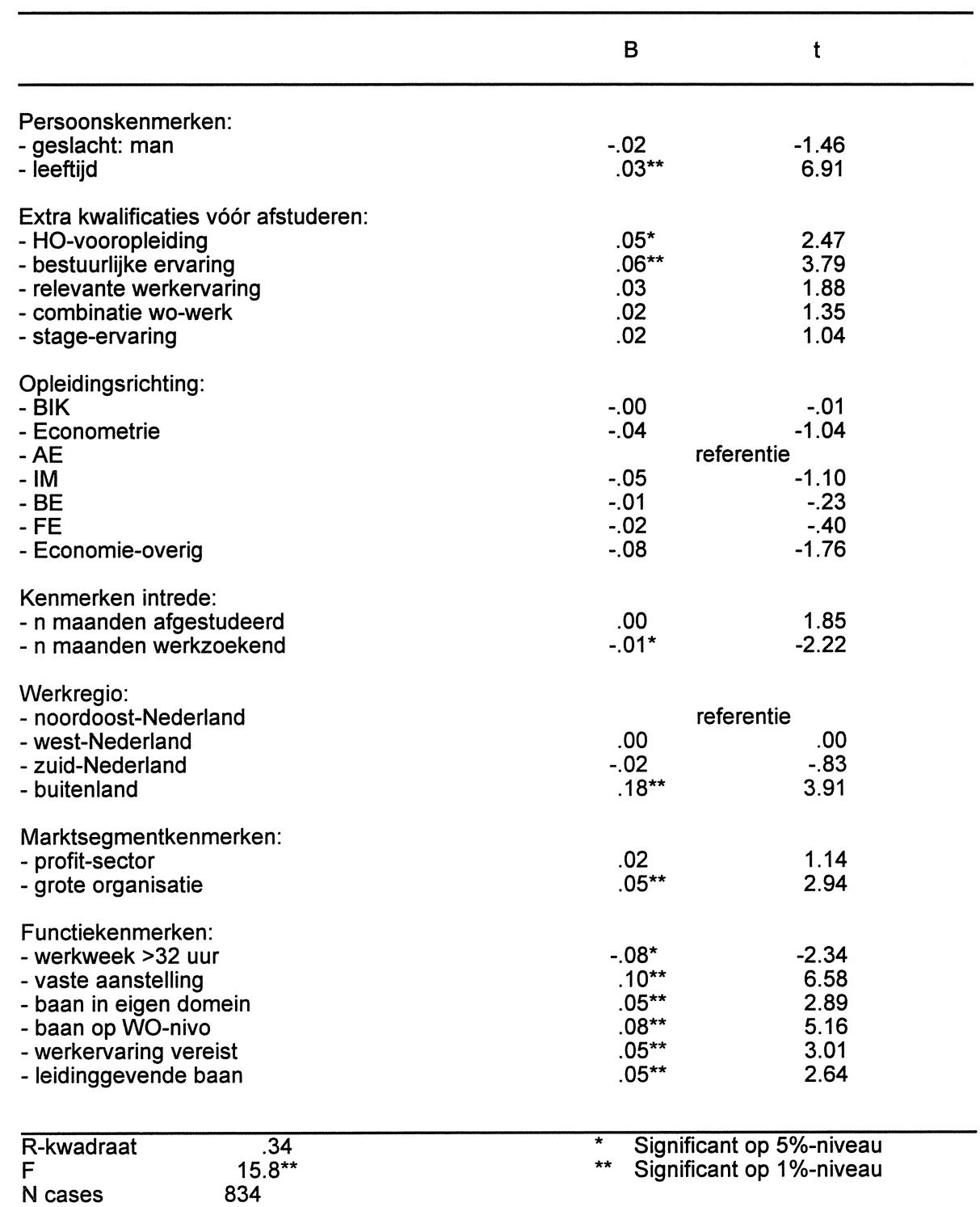

In de uitgevoerde analyse van het inkomen kan geen signifiant effect worden vastgesteld van het geslacht. Verder blijkt dat de opleidingen niet significant verschillen ten opzichte van de referentiecategorie AE.

De hoogte van het uurloon wordt bepaald door de leeftijd, enkele van de extra kwalificaties waarover men eventueel beschikt, de wijze waarop de arbeidsmarktin- 
trede is verlopen, de werkregio en de grootte van de werkorganisatie waarin men terecht komt alsmede de arbeidsparticipatie en -zekerheid en de eisen van functie die men uitoefent. Zo blijkt het inkomen toe te nemen met de leeftijd. Het inkomen is ook hoger wanneer men beschikt over additioneel menselijk kapitaal in de vorm van een hoger onderwijsdiploma voordat men economie is gaan studeren en bestuurlijke ervaring. Een slecht verlopen arbeidsmarktintrede (lang zoeken naar werk) blijkt niet bevorderlijk te zijn voor de hoogte van het inkomen. Verder komt naar voren dat men in het buitenland en in grote organisaties meer verdient. Hetzelfde geldt voor deeltijdfuncties en vaste banen.

In banen die passen bij het niveau en de richting van de gevolgde opleiding blijken afgestudeerden produktiever te zijn en bijgevolg meer te verdienen. Dit is ook het geval in leidinggevende functies en in functies waarvoor werkervaring is vereist. 



\section{Afstemming tussen opleiding en werk}

\subsection{Afstemming tussen opleidingskwalificaties en beroepspraktijk}

In dit hoofdstuk geven de economen eerst hun algemeen oordeel over de aansluiting tussen de gevolgde opleiding en het uitgeoefende werk. Vervolgens wordt nagegaan welke specifieke kwalificaties voor economen van belang zijn bij hun beroepsuitoefening en in hoeverre deze kwalificaties voldoende aan bod zijn gekomen tijdens de opleiding. In aansluiting hierop komt hun behoefte en deelname aan bijscholing aan bod.

Algemeen oordeel over de aansluiting tussen opleiding en werk

De overgrote meerderheid (83\%) van de betaald-werkende afgestudeerden beoordeelt de aansluiting tussen de door hen gevolgde economie-opleiding en het werk dat zij ten tijde van de enquête uitoefenen als goed of voldoende. Vorig jaar was $82 \%$ tevreden over de aansluiting tussen opleiding en werk.

Afgestudeerden van de opleidingen Economie-overig (71\%) en $A E(79 \%)$ zijn iets minder vaak tevreden over de aansluiting opleiding-werk dan afgestudeerden van de opleidingen BE (84\%), BIK (86\%), Econometrie (86\%), FE (86\%) en IM (88\%) .

\section{Kwalificaties}

Hieronder staan eventuele inhoudelijke discrepanties tussen het genoten economieonderwijs en het uitgeoefende werk centraal. Hiervan is sprake wanneer de kwalificaties die in het onderwijs worden bijgebracht niet passen bij de kwalificaties die worden vereist vanuit het werkveld. Het is daarbij van belang om op te merken dat hier uitsluitend het oordeel van de afgestudeerden aan bod komt. Dit hoeft niet overeen te stemmen met het oordeel vanuit het werkveld.

In de metingen die twee jaar geleden zijn uitgevoerd onder afgestudeerden van het hoger onderwijs, de HBO-Monitor 1994 en de WO-Scanner 1994, zijn voor het achterhalen van eventuele inhoudelijke discrepanties aan de betaald-werkende afgestudeerden 38 kwalificatie-aspecten voorgelegd die voor een goede uitoefening van hun functie van belang kunnen zijn. Hiertoe behoorden drie kwalificatie-aspecten die voor economie-opleidingen irrelevant zijn en waarover in de vorige disciplinerapportage derhalve niet is gerapporteerd ${ }^{1}$. Met behulp van principale factorenanalyse is later op het hele hoger onderwijs-bestand onderzocht of het grote aantal

1. Het betreft de aspecten 'kennis van toepassingsmogelijkheden materialen/hulpmiddelen', 'praktische handvaardigheden'en 'lichamelijke conditie'. 
aspecten kan worden herleid tot een beperkter aantal onderliggende dimensies en welke aspecten dan het meeste bijdragen aan deze dimensies. Er is geconcludeerd dat de 38 aspecten die het belang van de kwalificaties in de beroepspraktijk typeren goed herleidbaar zijn tot een achttal dimensies en dat 15 aspecten slechts in zeer geringe mate bijdragen aan de acht onderscheiden dimensies. Om deze reden is besloten om deze 15 aspecten niet langer aan de afgestudeerden voor te leggen. Vandaar dat in zowel de HBO-Monitor 1995 als de WO-Scanner 1995 voor het achterhalen van eventuele inhoudelijke discrepanties aan de betaald-werkende afgestudeerden een beperkter aantal van 23 kwalificatie-aspecten is voorgelegd die voor een goede uitoefening van hun functie van belang kunnen zijn. Deze kwalificatie-aspecten zijn zo geformuleerd dat zij voor mensen uit verscheidene werkvelden toepasbaar zijn.

Bij elk kwalificatie-aspect konden de oudstudenten eerst aangegeven in hoeverre zij het genoemde aspect van belang achten voor een goede vervulling van hun huidige werkzaamheden en vervolgens of in de door hen gevolgde opleiding meer, evenveel of minder aandacht aan dit aspect moet worden besteed (vergeleken met de hoeveelheid aandacht die het desbetreffende kwalificatie-aspect tijdens hun opleiding heeft gekregen). In deze paragraaf worden de resultaten over beide vragen in hun onderlinge samenhang besproken. Het is immers goed mogelijk dat afgestudeerden bepaalde aspecten weliswaar van groot belang achten voor het goed functioneren in de beroepspraktijk, maar dat zij desondanks niet vinden dat de faculteit aan dit aspect meer aandacht moet gaan besteden dan tijdens hun opleiding het geval was. Het moge duidelijk zijn dat bepaalde houdingsaspecten, hoe belangrijk wellicht ook in een functie, slechts gedeeltelijk kunnen worden aangeleerd tijdens een universitaire studie. Faculteiten kunnen soms nauwelijks meer doen dan de studenten tijdens hun opleiding op het belang van deze houdingsaspecten wijzen, hen daarin voor een deel trainen en aan deze aspecten tijdens de stage meer aandacht schenken. In dit verband is het ook belangrijk dat het (landelijke) onderwijsbeleid toelaat dat studenten voldoende tijd hebben om, naast de feitelijke studie, werkervaring en bestuurlijke ervaring op te doen. Juist deze ervaringen zijn bijzonder relevant voor het zich eigen maken van bepaalde sociale vaardigheden en houdingen.

De onderzochte kwalificatie-aspecten verwijzen naar eisen ten aanzien van kennis, vaardigheden en houdingen, die onder meer zijn ontleend aan literatuur over functieanalyse (zie o.a. Algera, $1991^{2}$ ). Deze aspecten lopen uiteen van vakkennis, inzicht in bedrijfsvoering en het plannen, organiseren en coördineren van activiteiten tot en met sociale vaardigheden zoals leidinggevende vaardigheden en contactuele

2. Algera, J.A. (redactie, 1991), Analyse van arbeid vanuit verschillende perspectieven, Swets \& Zeitlinger, Amsterdam/Lisse. 
vaardigheden en aspecten ten aanzien van de werkhouding zoals aanpassingsvermogen en loyaliteit. Zoals eerder gezegd, zijn de aspecten zo geformuleerd dat zij voor mensen uit verscheidene werkvelden toepasbaar zijn.

Uiteraard kunnen strikt individuele factoren bij de oordelen van de respondenten een rol spelen, waardoor er tussen de afgestudeerden een behoorlijke variatie kan bestaan in het oordeel over de opleiding. Afhankelijk van de persoonlijke (werk)omstandigheden kan het oordeel de ene keer iets positiever en de andere keer iets negatiever uitvallen. Gemiddeld genomen vallen deze afwijkingen waarschijnlijk tegen elkaar weg, waardoor in totaal een valide beeld ontstaat over de aansluiting tussen de gevolgde opleiding en de functie. Tabel 4.1 geeft een beeld van het belang voor de beroepsuitoefening van de onderscheiden kwalificaties en het oordeel of de betreffende kwalificaties in de opleiding voldoende aan bod zijn gekomen.

De afgestudeerden konden het belang dat zij aan een bepaald kwalificatie-aspect toekennen op een vierpuntsschaal aangeven. Deze schaal bevat de categorieën: onbelangrijk, vrij onbelangrijk, tamelijk belangrijk en zeer belangrijk. In tabel 4.1 staat in de kolom 'belang' voor ieder aspect het percentage betaald-werkende afgestudeerden dat het betreffende aspect tamelijk of zeer belangrijk vindt voor een goede uitoefening van de functie.

De aspecten vormen zoals hierboven al aangegeven verschillende indicatoren voor een aantal onderliggende dimensies. Omwille van de inzichtelijkheid is ook dit jaar met behulp van principale factorenanalyse nagegaan of het grote aantal aspecten kan worden herleid tot een handzaam aantal dimensies. Middels factoranalyse kan namelijk worden nagegaan welke kwalificatie-aspecten in de beroepspraktijk vaak met elkaar verweven zijn en in feite een gemeenschappelijke 'set' van kwalificatieaspecten vormen. Hierbij is de samenhang binnen de dimensies groot, terwijl de samenhang tussen de dimensies gering is. In de uitgevoerde principale factorenanalyse is één aspect, namelijk 'fysieke vaardigheden, handvaardigheden, motoriek' niet meegenomen aangezien dit aspect voor economische opleidingen irrelevant is.

De bevinding is dat de 22 in de analyse opgenomen kwalificatie-aspecten, op basis van hun belang voor de beroepsuitoefening, herleidbaar zijn tot vijf dimensies of factoren (eigenwaarde $>=1$ ), die tesamen $55 \%$ van de variantie in het factor analytisch model voor hun rekening nemen. Deze vijf factoren zijn: juiste werkhouding, commercieel management, dataverwerking \& -beheer, onderzoek \& presentatie en theoretische \& praktische vakkennis. De vijf factoren staan vermeld in tabel 4.1. In de tabel staan bij iedere factor tevens de kwalificatie-aspecten vermeld, die na varimax rotatie het hoogste op de desbetreffende factor laden. Bij iedere factor staat 
het kwalificatie-aspect met de hoogste lading steeds als eerste vermeld en het aspect met de laagste lading steeds als laatste.

Tabel 4.1

Afstemming tussen onderwijs en beroepspraktijk

Belangrijk Meer aandacht

in praktijk nodig

1) Juiste werkhouding

- nauwkeurigheid, zorg

aliteit, integriteit

aanpassingsvermogen, functioneren onder werkdruk

- zelfstandigheid, initiatief, creativiteit

systematische reflectie, terugkoppeling, feedback

$91 \% \quad 26 \%$

$96 \% \quad 25 \%$

$98 \% \quad 30 \%$

2) Commercieel management

onderhandelingstechnische en commerciële vaardigheden

$89 \% \quad 20 \%$

- mondelinge presentatie, spreekvaardigheid

- contactuele vaardigheden

- plannen, coördineren, organiseren activiteiten

- leidinggevende en didactische vaardigheden

- inzicht in bedrijfsvoering (organ/financ/admin)

$79 \% \quad 54 \%$

$94 \% \quad 57 \%$

$96 \% \quad 37 \%$

$89 \% \quad 31 \%$

$70 \% \quad 37 \%$

3) Dataverwerking en -beheer

\section{inzicht in informatie- \& communicatietechnologie}

$83 \% \quad 27 \%$

- verzamelen/documenteren informatie, gegevensbeheer

$88 \% \quad 49 \%$

$81 \% \quad 21 \%$

4) Onderzoek en presentatie

- analytische en diagnostische (onderzoeks)vaardigheden schriftelijke presentatie, schrijfvaardigheid

taalvaardigheid (beheersing vreemde talen)

kwantitatieve (onderzoeks)vaardigheden

$80 \% \quad 22 \%$

$91 \% \quad 46 \%$

$64 \% \quad 35 \%$

$\begin{array}{ll}64 \% & 35 \% \\ 82 \% & 16 \%\end{array}$

5) Theoretische en praktische vakkennis

vakkennis

$86 \% \quad 13 \%$

recente ontwikkelingen in het vakgebied

vakspecifieke methoden en technieken

inzicht in wettelijke regelingen eigen vakgebied

$77 \% \quad 35 \%$

$77 \% \quad 20 \%$

toepassen kennis \& technieken in de praktijk

$\begin{array}{ll}54 \% & 18 \% \\ 79 \% & 44 \%\end{array}$

Uit tabel 4.1 blijkt dat alle genoemde kwalificatie-aspecten door de meerderheid van de economen belangrijk worden geacht voor het vervullen van de functie. Bij 19 van de 22 aspecten vindt zelfs tenminste driekwart van de betaald-werkende afgestudeerden dat dit aspect belangrijk is voor een goede uitoefening van de functie. De genoemde aspecten zijn blijkbaar in hoge mate relevant voor het typeren van de kwalificaties die de afgestudeerde economen bij hun arbeidsmarktintrede nodig hebben.

Een juiste werkhouding wordt het vaakst van belang geacht voor het goed kunnen functioneren in het werk. Het gaat hierbij om kwalificatie-aspecten waarbij gemiddeld $94 \%$ van de economen heeft aangegeven dat deze belangrijk zijn voor de functievervulling. Na een juiste werkhouding worden kwalificaties op het gebied van 
commercieel management en dataverwerking en -beheer van belang geacht voor een goede uitoefening van de functie. De desbetreffende kwalificatie-aspecten worden door gemiddeld $85 \%$ van de betaald-werkende economen tamelijk of zeer belangrijk gevonden voor een goede functie-uitoefening. Vaardigheden op het terrein van onderzoek en presentatie (gemiddeld $79 \%$ belangrijk) alsmede theoretische en praktische vakkennis (gemiddeld $75 \%$ ) worden iets minder vaak 'economiebreed' als belangrijke kwalificatievereisten genoemd. Uit de factorenanalyse komt overigens heel duidelijk de samenhang naar voren tussen de vakkennis en -technieken en de praktische toepassing daarvan.

Door het volgen van opleidingen moeten mensen dié kwalificaties leren die nodig zijn om meer of minder gespecialiseerde arbeidsprestaties te kunnen leveren. Vanuit de arbeidsmarkt bezien, moet een opleiding derhalve in de juiste mate aandacht besteden aan kwalificaties die van belang zijn voor een goede beroepsuitoefening. Daarom is nagegaan of de genoemde beroepsrelevante kwalificatie-aspecten tijdens de opleiding wel voldoende aan bod zijn gekomen volgens de afgestudeerden (het is overigens nog maar de vraag of juist tijdens de economie-opleiding meer aandacht moet en kan worden geschonken aan bijvoorbeeld de juiste houdingsaspecten, die bij de overgang van een opleiding naar een werkkring zo belangrijk blijken te zijn).

De betaald-werkende afgestudeerden konden in de vragenlijst per aspect aangeven of hieraan tijdens de door hen gevolgde studie meer, evenveel of minder aandacht moet worden besteed. Hierbij moet worden opgemerkt dat afgestudeerden zich niet altijd realiseren dat meer aandacht voor het ene aspect, bij een gelijkblijvende studieduur, minder aandacht voor een ander aspect betekent.

Wanneer de resultaten over het belang van de kwalificaties in de beroepspraktijk worden vergeleken met de resultaten over de benodigde aandacht hiervoor, valt op dat de kwalificatie-aspecten die het vaakst van belang blijken te zijn bij het uitoefenen van de functie, niet altijd de aspecten zijn waaraan volgens de afgestudeerden meer aandacht zou moeten worden besteed tijdens de economie-opleiding. Terwijl bijvoorbeeld $97 \%$ van de betaald-werkende economen van mening is dat nauwkeurigheid en zorgvuldigheid van belang is voor het goed kunnen functioneren in de functie, vindt 'slechts' $15 \%$ dat er tijdens de economie-opleiding meer aandacht moet zijn voor dit aspect. Dit laat onverlet dat er ook houdingsaspecten zijn waarvoor wel relatief vaak meer aandacht wordt gevraagd, bijvoorbeeld voor zelfstandigheid, initiatief, creativiteit.

Uit tabel 4.1 blijkt verder dat tenminste $40 \%$ van de betaald-werkende economen meer aandacht nodig acht voor mondelinge presentatie/spreekvaardigheid, onderhandelingstechnische en commerciële vaardigheden, inzicht in informatie- \& communicatietechnologie, schriftelijke presentatie/schrijfvaardigheid en de praktische toepassing van kennis. Dit betekent dat er tijdens de economie-opleiding meer 
ruimte zou moeten zijn voor training op deze terreinen, hetzij in aanvullende lessen (in het geval van inzicht in informatie- \& communicatietechnologie), hetzij door een andere vormgeving van het bestaande onderwijs (in het geval van mondelinge presentatie/spreekvaardigheid, onderhandelingstechnische en commerciële vaardigheden, schriftelijke presentatie/schrijfvaardigheid en de praktische toepassing van kennis). Ook stages lenen zich goed voor het aanleren van dergelijke vaardigheden. De faculteiten zouden ook nascholingscursussen op deze terreinen kunnen aanbieden.

Met betrekking tot de kennis en vaardigheden die direct verband houden met het vakgebied economie zou de faculteit zich volgens de afgestudeerden vooral meer moeten richten op de praktische toepassingsmogelijkheden van de vakkennis en op de actualiteit daarvan. Aan de vakkennis zelf wordt naar de mening van de afgestudeerden voldoende aandacht besteed tijdens de economie-opleiding: hoewel $86 \%$ vakkennis belangrijk acht voor het goed kunnen uitoefenen van de functie, is 'slechts' $13 \%$ van mening dat hieraan tijdens de economie-opleiding meer aandacht zou moeten worden besteed.

$\mathrm{Er}$ is ook nagegaan of de economie-opleidingen verschillen ten aanzien van het belang dat de onderscheiden kwalificatieclusters hebben voor een goede beroepsuitoefening van hun afgestudeerden. Zoals eerder vermeld, is het belang voor een goede beroepsuitoefening gemeten op de volgende vierpuntsschaal: 1 = onbelangrijk, 2 = vrij onbelangrijk, $3=$ tamelijk belangrijk en $4=$ zeer belangrijk. Tabel 4.2 geeft per opleiding een beeld van het gemiddelde belang van de onderscheiden 5 kwalificatieclusters. Het gemeten belang van de desbetreffende onderliggende aspecten (zie tabel 4.1) is hierbij gewogen met behulp van hun factorladingen. Het aldus berekende gewogen gemiddelde van het desbetreffende kwalificatiecluster is vervolgens vermenigvuldigd met: $1 /$ de gemiddelde factorlading, om te corrigeren voor het aantal aspecten dat op het desbetreffende cluster laadt en daarmee voor verschillen in gemiddelde factorladingen tussen de kwalificatieclusters. Op deze wijze berekend, krijgen aspecten die belangrijker zijn voor het cluster een groter gewicht toegekend.

Bij alle opleidingen kan worden geconstateerd dat een juiste werkhouding voor de afgestudeerden het meest belangrijk is om goed in het beroep te kunnen functioneren. Verder blijkt dat kennis en vaardigheden op het gebied van commercieel management meer dan gemiddeld belangrijk zijn voor afgestudeerden IM, kennis en vaardigheden met betrekking tot dataverwerking en -beheer voor afgestudeerden BIK en theoretische en praktische vakkennis voor fiscaal economen. 


\subsection{Behoefte en deelname aan bijscholing}

Aansluitend op de voorgaande paragraaf over de afstemming tussen het economieonderwijs en de beroepspraktijk, wordt hieronder de omvang van de behoefte en deelname aan bijscholing geschetst. Vervolgens wordt aangegeven waarom men bijscholing volgt en wie de bijscholing verzorgt.

Bijna de helft (44\%) van alle afgestudeerden heeft behoefte aan bijscholing. Dit is nagenoeg gelijk aan de $46 \%$ bij de vorige enquête. De behoefte aan bijscholing is het hoogst onder afgestudeerden IM en het laagst onder fiscaal economen. In tabel 4.3 komt verder naar voren dat bijna de helft (45\%) van alle afgestudeerden daadwerkelijk heeft deelgenomen aan bijscholing ${ }^{3}$. Afgestudeerden IM hebben het minst vaak daadwerkelijk bijscholing gevolgd. Vooral onder afgestudeerden IM heeft de behoefte aan bijscholing (60\%) niet noodzakelijkerwijze geleid tot daadwerkelijke deelname aan bijscholing (40\%), wellicht mede als gevolg van het ontbreken van voldoende geschikt aanbod van bijscholingscursussen.

Tabel 4.4 laat zien dat de meeste (52\%) deelnemers aan bijscholing aanvullende opleidingen of cursussen volgen om zich verder te specialiseren binnen het eigen vakgebied. Eén op de drie deelnemers (36\%) volgt bijscholing om het eigen vakgebied te verbreden en $4 \%$ om bij te blijven in het eigen vakgebied. Een op de tien deelnemers aan bijscholing ( $9 \%$ ) volgt daarentegen een aanvullende opleiding of cursus omdat zij zich willen omscholen naar een ander vakgebied.

Afgestudeerden van de opleidingsrichtingen BIK, IM, BE, FE en Economie-overig volgen meestal bijscholing om zich verder te specialiseren binnen het eigen vakgebied. Econometristen en afgestudeerden $A E$ volgen meestal bijscholing vanwege verbreding van het eigen vakgebied. Econometristen volgen daarnaast vaker dan gemiddeld bijscholing omdat zij zich willen omscholen naar een ander vakgebied.

Bij bijna de helft van de deelnemers aan bijscholing worden de cursussen verzorgd door partikuliere opleidingsinstituten $(43 \%)$ en bij ruim een kwart $(28 \%)$ door het eigen bedrijf of instelling. De resterende cursussen worden verzorgd door bedrijfstakorganisaties $(12 \%)$, universiteiten $(9 \%)$, hogescholen $(2 \%)$ of door andere aanbieders $(6 \%)$.

3. Aan de faculteiten is via de faculteitsrapportage doorgegeven welke aanvullende opleidingen en cursussen door de afgestudeerden zijn gevolgd. 


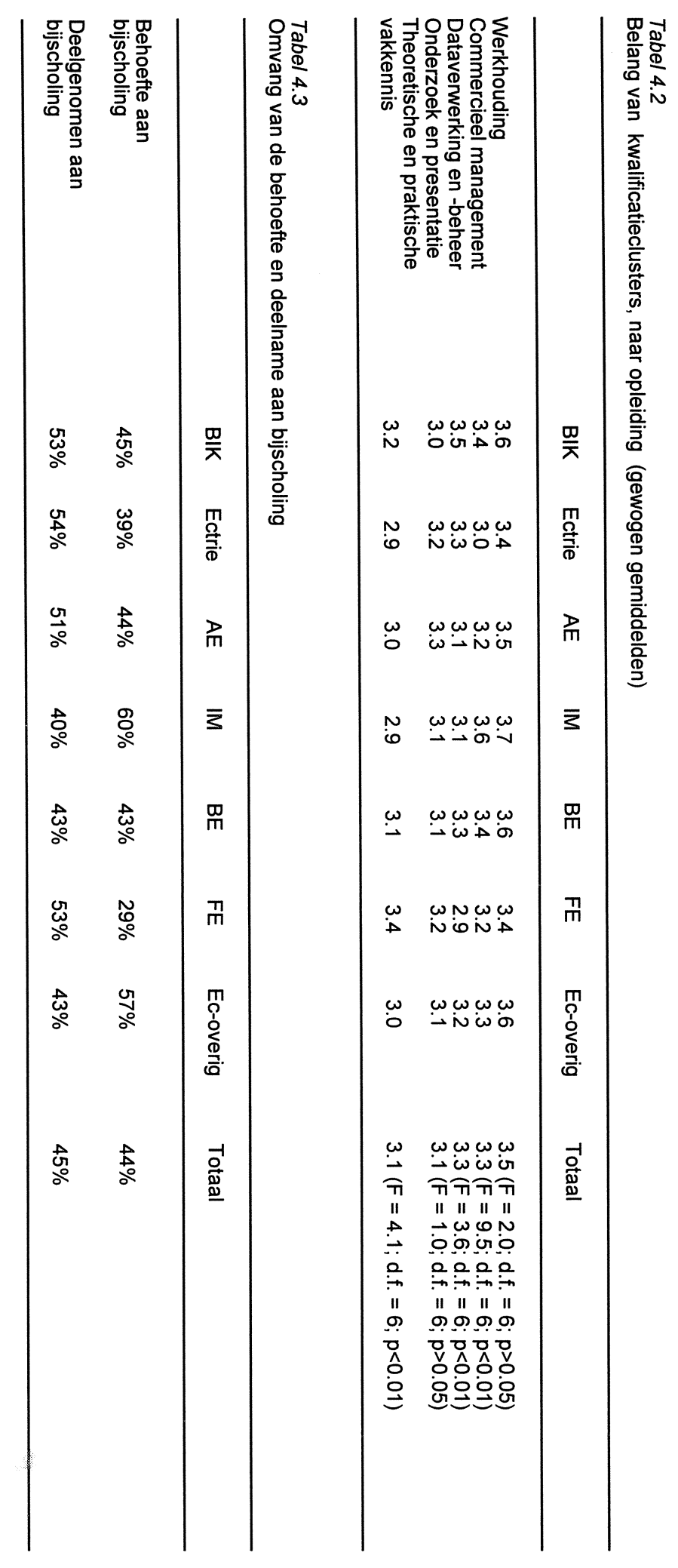




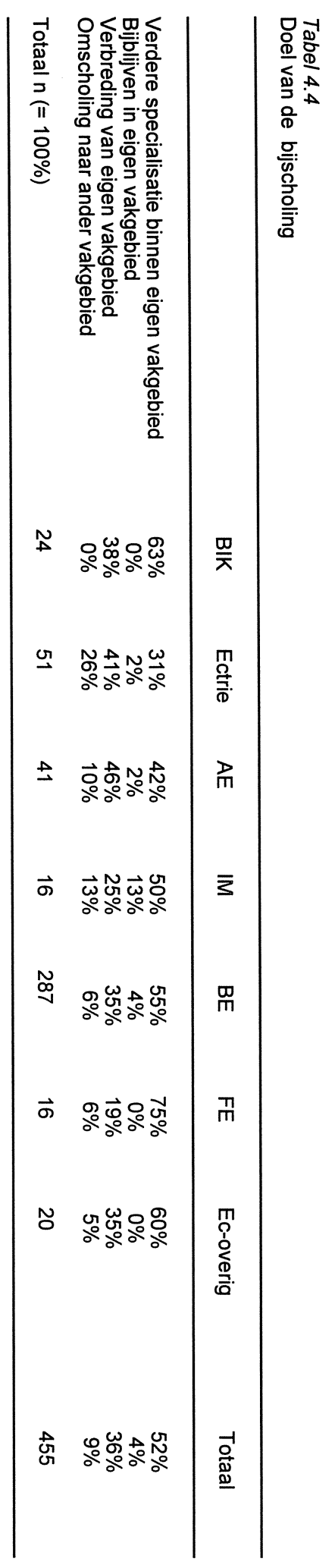


Het eigen bedrijf of instelling verzorgt het vaakst de bijscholing van afgestudeerden BIK (52\%) en Economie-overig (41\%). Particuliere opleidingsinstituten verzorgen het vaakst de bijscholing van econometristen $(56 \%)$ en van afgestudeerden $\mathrm{AE}(49 \%)$, IM (44\%) en BE (41\%). Particuliere opleidingsinstituten en bedrijfstakorganisaties (elk met een aandeel van $35 \%$ ) verzorgen het vaakst de bijscholing van fiscaal economen. 


\section{Opleiding achteraf bezien}

\subsection{Gewenste bijstelling van het onderwijs}

In dit hoofdstuk wordt eerst aangegeven in welke richting een aantal aspecten van het economie-onderwijs naar de mening van de afgestudeerden zou moeten worden bijgesteld. Vervolgens wordt ingegaan op de vraag of de afgestudeerden, achteraf bezien, opnieuw dezelfde opleiding zouden kiezen.

Aan alle afgestudeerden, dus ook degenen die niet betaald-werken, is voor de volgende aspecten de vraag voorgelegd óf de faculteit het onderwijs zou moeten bijstellen en zo ja in welke richting deze bijstelling dient plaats te vinden:

- samenhang in onderwijsonderdelen;

- keuzemogelijkheden in de studie;

- specialisatie van de opleiding;

- zwaarte/moeilijkheidsgraad van de opleiding;

- studiebegeleiding;

- oriëntatie op toekomstig beroepenveld.

Tabel 5.1 laat zien dat de meeste afgestudeerden vinden dat het economie-onderwijs tekortschiet wat de oriëntatie op het toekomstige beroepenveld betreft. De samenhang in onderwijsonderdelen van de opleiding, de keuzemogelijkheden in de studie, de mate waarin de opleiding is gespecialiseerd, de zwaarte van de opleiding en de studiebegeleiding hoeven volgens de meeste afgestudeerden niet te worden bijgesteld. Dit laat onverlet dat nog altijd zo'n vier op iedere tien afgestudeerden van mening zijn dat de samenhang tussen de onderwijsonderdelen voor verbetering vatbaar is, dat een op de drie afgestudeerden vindt dat er meer studiebegeleiding nodig is, en dat een op de vijf afgestudeerden meer keuzemogelijkheden in de studie wenst of van mening is dat de opleiding meer gespecialiseerd zou kunnen zijn. Een opmerkelijk resultaat is verder dat maar liefst een derde van de afgestudeerden van mening is dat de opleiding zwaarder zou mogen worden, terwijl vrijwel geen enkele afgestudeerde zegt dat de opleiding minder zwaar zou moeten zijn.

Uitgesplitst naar opleiding ontstaat het volgende beeld. Afgestudeerden BIK vinden vaker dan gemiddeld dat er te weinig keuzemogelijkheden in de studie zijn. Zij zijn wel vaker dan gemiddeld tevreden over de studiebegeleiding. Econometristen zijn vaker dan gemiddeld tevreden over de zwaarte/moeilijkheidsgraad van de opleiding, terwijl algemeen economen relatief vaak vinden dat de opleiding best wat $z$ waarder zou mogen zijn. Afgestudeerden IM geven nog vaker dan anderen aan dat de opleiding tekortschiet wat de oriëntatie op het toekomstige beroepenveld betreft. Fiscaal economen zijn vaker dan gemiddeld tevreden over de samenhang in 


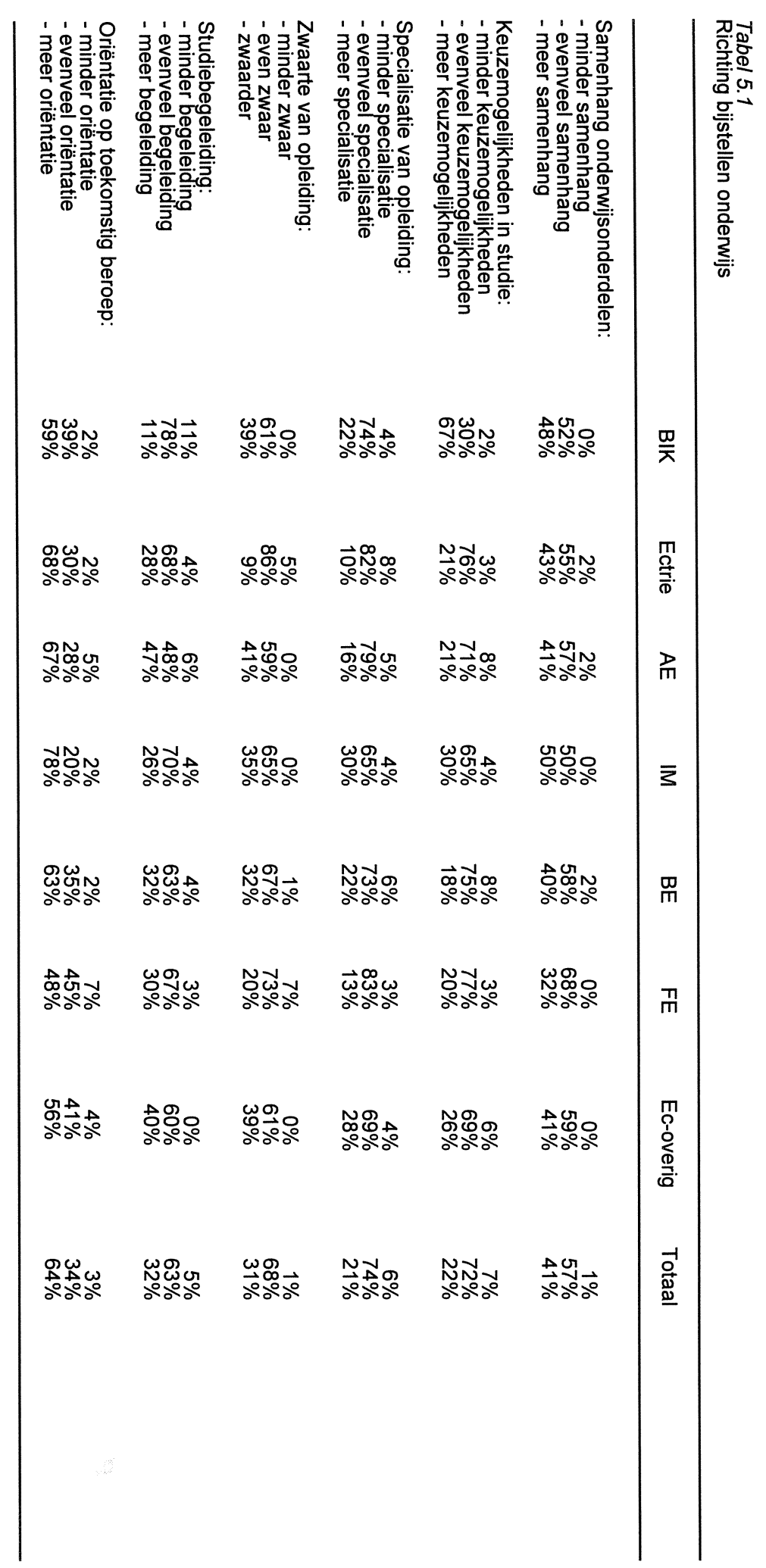




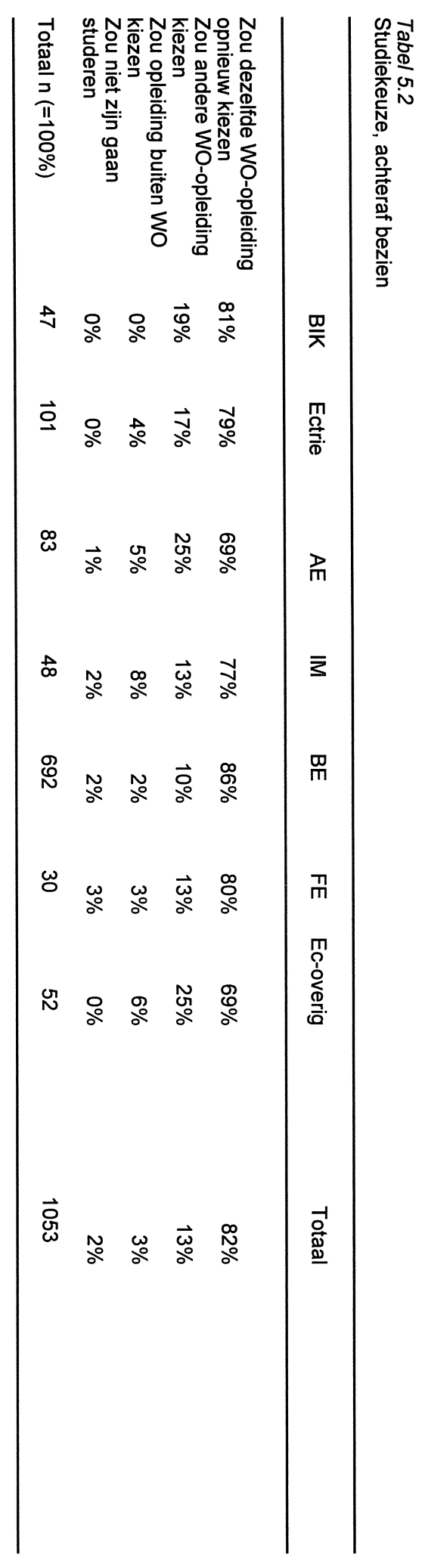


onderwijsonderdelen van de opleiding en de oriëntatie op de toekomstige beroepsmogelijkheden.

\subsection{Studiekeuze achteraf bezien}

In deze paragraaf komt de vraag aan de orde of de afgestudeerden achteraf bezien opnieuw dezelfde opleiding zouden kiezen. Het antwoord op deze vraag kan worden beschouwd als een indicatie van hun algemeen oordeel over de gevolgde economieopleiding.

Vier op de vijf afgestudeerden (82\%) zouden, achteraf bezien, opnieuw voor dezelfde opleiding kiezen (tabel 5.2). Eén op iedere acht afgestudeerden (13\%) zou een andere academische opleiding kiezen. Slechts $4 \%$ betreurt de destijds genomen studiekeuze: zij zouden, achteraf bezien, niet zijn gaan studeren maar bijvoorbeeld direct zijn gaan werken (2\%) of een niet-universitaire opleiding zijn gaan volgen (2\%). Deze cijfers komen vrijwel overeen met die in de vorige enquête. Toch kwam naar voren dat $81 \%$ achteraf bezien opnieuw voor dezelfde opleiding zou kiezen, $15 \%$ voor een andere academische opleiding, $3 \%$ voor een niet-universitaire opleiding, terwijl $1 \%$, achteraf bezien, niet zou zijn gaan studeren.

Tabel 5.2 laat verder zien dat afgestudeerden AE en Economie-overig iets vaker dan gemiddeld achteraf een andere academische opleiding zouden hebben gekozen. 


\section{Thema: Sexeverschillen bij arbeidsmarktintrede}

In economische opleidingen vormen vrouwen nog steeds een minderheid: 'slechts' een kwart $(24 \%)$ van de respondenten bestaat uit vrouwen. In overleg met de participerende faculteiten is besloten om eventuele sexeverschillen bij de transitie van opleiding naar beroep als thema nader te onderzoeken. Dit gebeurt aan de hand van de dimensies kans op werk en kwaliteit van het werk. Alvorens hier op in te gaan, worden eerst de eventuele verschillen in kwalificaties besproken waarmee mannelijke en vrouwelijke afgestudeerden de arbeidsmarkt betreden. Deze kunnen verband houden met de genoten vooropleiding, de gevolgde economische opleidingsrichting en de eventuele werk- en bestuurlijke ervaring die zij vóór of tijdens de economie-opleiding hebben opgedaan.

Vooropleiding

Tabel 6.1 laat zien dat de vooropleiding van vrouwelijke economen niet significant verschilt van die van mannelijke economen. Dat wil zeggen dat de kans dat de geconstateerde verschillen in genoten vooropleiding op toeval berusten groter dan $5 \%$ is.

Tabel 6.1

Hoogst voltooide vooropleiding naar geslacht

\begin{tabular}{lcc}
\hline & Mannen & Vrouwen \\
\hline WwO & $78 \%$ & $81 \%$ \\
HBO & $20 \%$ & $17 \%$ \\
WO & $1 \%$ & $0 \%$ \\
Andere & $1 \%$ & $2 \%$ \\
Totaal $n(=100 \%)$ & 818 & 261 \\
\hline
\end{tabular}

$x^{2}=4.2 ;$ d.f. $=3 ; p=.24$

\section{Studiekeuze}

Niet alleen wat de genoten vooropleiding maar ook wat de gekozen economische opleidingsrichting betreft, verschillen mannelijke en vrouwelijke afgestudeerden nauwelijks van elkaar (tabel 6.2). Zij verschillen wel in leeftijd: de mannelijke afgestudeerden zijn gemiddeld ouder dan de vrouwelijke afgestudeerden. Op het moment van enquêteren waren de mannelijke respondenten gemiddeld 26,5 jaar en de vrouwelijke respondenten 25,8 jaar (significantie F-toets: <0.01). 
Tabel 6.2

Gevolgde opleiding naar geslacht

\begin{tabular}{lrr}
\hline & Mannen & Vrouwen \\
\hline BIK & $5 \%$ & $3 \%$ \\
Ectrie & $9 \%$ & $12 \%$ \\
$\mathrm{AE}$ & $8 \%$ & $9 \%$ \\
$\mathrm{IM}$ & $4 \%$ & $6 \%$ \\
$\mathrm{BE}$ & $68 \%$ & $60 \%$ \\
$\mathrm{FE}$ & $3 \%$ & $3 \%$ \\
Ec-overig & $5 \%$ & $6 \%$ \\
Totaal $\mathrm{n}(=100 \%)$ & 831 & 265 \\
\hline
\end{tabular}

$x^{2}=10.0 ;$ d.f. $=6 ; p=.12$

Werk- en bestuurlijke envaring

De resultaten in tabel 6.3 laten zien dat mannen over iets meer additionele kwalificaties in de vorm van werk- en bestuurlijke ervaring beschikken wanneer zij de arbeidsmarkt betreden dan vrouwen. De verschillen zijn echter te gering om significant te zijn.

Tabel 6.3

Werk- en bestuurlijke ervaring naar geslacht

\begin{tabular}{lrll}
\hline & Mannen & Vrouwen & \\
\hline $\begin{array}{l}\text { Relevante werkervaring } \\
\text { Bestuurlijke ervaring }\end{array}$ & $55 \%$ & $54 \%$ & $x^{2}=0.1 ;$ d.f. $=1 ; p=.25$ \\
Combineren studie-werk & $60 \%$ & $55 \%$ & $x^{2}=1.9 ;$ d.f. $=1 ; p=.17$ \\
Stage-ervaring & $29 \%$ & $26 \%$ & $x^{2}=1.1 ;$ d.f. $=1 ; p=.30$ \\
& $65 \%$ & $70 \%$ & $x^{2}=2.0 ;$ d.f. $=1 ; p=.16$ \\
\hline
\end{tabular}

Kans op werk

Nadat hierboven is ingegaan op de verschillen in kwalificaties waarmee mannelijke en vrouwelijke afgestudeerden de arbeidsmarkt betreden, worden hieronder eventuele sexeverschillen bij de kans op werk in kaart gebracht. Dit gebeurt aan de hand van de volgende vier indicatoren:

- het snel (binnen drie maanden) vinden van werk;

- de werkloosheid op het moment van de enquête;

- het hebben van een full-time baan (arbeidsparticipatie).

- het hebben van een vaste aanstelling (werkzekerheid);

Gebleken is dat vrouwen even snel werk vinden als mannen. Van de mannen is $78 \%$ na het afstuderen niet of hooguit drie maanden werkzoekend geweest. Bij de vrouwen bedraagt het percentage $79 \%\left(x^{2}=.1\right.$; d.f. $\left.=1 ; p=.78\right)$. Zij zijn ook 
nagenoeg even vaak werkloos namelijk $6 \%$ van de mannen en $4 \%$ van de vrouwen $\left(x^{2}=1.6 ;\right.$ d.f. $\left.=1 ; p=.20\right)$. Ook wat de arbeidsparticipatie betreft, doen zich geen verschillen tussen mannen en vrouwen voor. Zowel onder de betaald-werkende mannen als onder de betaald-werkende vrouwen bedraagt het aandeel van personen met een full-time baan (>32 uur per week) $96 \%\left(x^{2}=.0\right.$; d.f. $\left.=1 ; p=.83\right)$. Niet alleen ten aanzien van de snelheid waarmee werk wordt gevonden en de mate van participatie aan het arbeidsproces maar ook ten aanzien van de zekerheid van het werk verschillen vrouwelijk economen niet significant van hun mannelijke collega's: $56 \%$ van de betaald-werkende mannen en $54 \%$ van de betaald-werkende vrouwen heeft een vaste aanstelling $\left(x^{2}=.3 ;\right.$ d.f. $\left.=1 ; p=.60\right)$.

Deze resultaten werden ook bevestigd door de multivariate analyses die besproken zijn in de vorige hoofdstukken. Daaruit bleek dat geslacht geen significant effect had op de kans om snel werk te vinden en een vaste baan te krijgen.

\section{Kwaliteit van het werk}

$\mathrm{Na}$ de bespreking van de kans op werk van mannelijke en vrouwelijke afgestudeerden komen de eventuele sexeverschillen bij de kwaliteit van het gevonden werk aan bod. Deze worden aan de hand van de volgende vier indicatoren onderzocht:

- het hebben van een baan waarvoor een opleiding op academisch niveau is vereist;

- het hebben van werk waarvoor de eigen- of een daaraan verwante opleidingsrichting is vereist;

- het uitoefenen van een leidinggevende functie;

- de hoogte van het bruto uurloon.

Niet alleen wat de kans op werk betreft maar ook wat het niveau van het werk betreft, doen zich geen significante verschillen voor tussen mannelijke en vrouwelijke economen: $54 \%$ van de betaald-werkende mannen en $51 \%$ van de betaaldwerkende vrouwen heeft een functie waarvoor een opleiding op universitair niveau is vereist $\left(x^{2}=.8\right.$; d.f. $=1 ; p=.36$ ). Verder blijkt dat vrouwelijke economen nagenoeg even vaak in het eigen beroependomein terecht komen als mannelijke economen: van de betaald-werkende mannen is $78 \%$ in het eigen domein werkzaam en van de betaald-werkende vrouwen $74 \%\left(x^{2}=1.3\right.$; d.f. $\left.=1 ; p=.26\right)$.

Mannen blijken wel significant vaker leidinggevende functies te bekleden dan vrouwen: van de betaald-werkende mannen heeft $23 \%$ een leidinggevende functie, tegen $15 \%$ van de betaald-werkende vrouwen $\left(x^{2}=8.3\right.$; d.f. $\left.=1 ; p=.00\right)$. Dit laat onverlet dat de variabele geslacht geen significant effect heeft op de kans om een leidinggevende functie te krijgen. Dat mannen desondanks vaker leidinggevende functies hebben, hangt samen met de bevinding dat zij hoger scoren op kenmerken die de kans op een leidinggevende functie vergroten, namelijk leeftijd, werk- en 
bestuurlijke ervaring waarover men eventueel beschikt en de grootte van de organisatie waarin men terecht komt (zie de analyseresultaten van de kans op een leidinggevende functie in tabel 3.7). De betaald-werkende mannelijke respondenten zijn gemiddeld iets ouder dan hun vrouwelijke collega's (26,4 jaar tegen 25,6 jaar) en de kans op een leidinggevende functie neemt toe met de leeftijd. De betaaldwerkende mannelijke afgestudeerden beschikken vaker dan vrouwen over bestuurlijke ervaring $(60 \%$ versus $55 \%)$ en voor hun vakgebied relevante werkervaring $(57 \%$ versus $54 \%$ ), waardoor hun kans op een leidinggevende baan groter is. Daarbij komt dat mannen iets vaker dan vrouwen ( $25 \%$ versus $22 \%$ ) in kleine organisaties werken waar de kans op een leidinggevende functie groter is.

Mannen blijken niet alleen vaker dan vrouwen leidinggevende functies te verwerven maar gemiddeld ook iets meer (hoewel niet significant) te verdienen, namelijk bijna 50 cent bruto per uur. Dit is echter niet bij alle opleidingen het geval. Zo laat tabel 6.4 zien dat onder afgestudeerden BIK, AE, IM en Economie-overig vrouwen per uur meer verdienen dan mannen.

Tabel 6.4

Gemiddeld bruto uurloon in hoofdfunctie, per opleiding naar geslacht

\begin{tabular}{lll}
\hline & Mannen & Vrouwen \\
\hline BIK & 22,37 & 22,61 \\
Ectrie & 21,87 & 20,18 \\
AE & 21,38 & 22,32 \\
IM & 22,02 & 22,21 \\
BE & 22,70 & 22,21 \\
FE & 23,85 & 22,69 \\
Ec-overig & 22,21 & 22,70 \\
Totaal & 22,50 & 22,02 \\
\hline
\end{tabular}

Resumé

Als algemene conclusie komt naar voren dat vrouwelijke economen nauwelijks verschillen van mannelijke economen ten aanzien van de kwalificaties waarmee zij de arbeidsmarkt betreden, de kans op werk en de kwaliteit van het gevonden werk. Mannen blijken wel vaker leidinggevende functies te bekleden dan vrouwen omdat zij gemiddeld wat ouder zijn, meer over bestuurlijke ervaring beschikken en vaker in kleine organisaties werken. Deze aspecten vergroten de kansen op een leidinggevende functie. 


\section{Bijlage 1 Verklarende variabelen}

Geslacht: man

Leeftijd

HO-vooropleiding

Bestuurlijke ervaring

Relevante werkervaring

Combinatie wo-werk

Stage-ervaring

Opleidingsrichting:

- BIK

- Econometrie

- $A E$

$-I M$

- BE

- Economie-overig

$N$ maanden afgestudeerd

$N$ maanden werkzoekend

Werkregio:

- Noordoost-Nederland

- West-Nederland

- Zuid-Nederland

- buitenland

- Profit-sector

- Grote organisatie

Werkweek $>32$ uur dummy = 1 indien respondent man is

leeftijd in jaren op het moment van de enquête.

dummy = 1 indien respondent eerder een HBO- of WOopleiding heeft voltooid.

dummy = 1 indien respondent vóór of tijdens de opleiding bestuurlijke ervaring heeft opgedaan.

dummy = 1 indien respondent vóór of tijdens de opleiding voor het vakgebied relevante (on)betaalde werkervaring heeft opgedaan.

dummy $=1$ indien respondent gedurende de gehele opleiding betaald werk heeft verricht voor minimaal 12 uur per week.

dummy = 1 indien respondent tijdens de opleiding stage heeft gelopen.

dummy = 1 indien bestuurlijke informatiekunde; dummy $=1$ indien econometrie

dummy $=0$ indien algemene economie (referentiecategorie)

dummy = 1 indien internationaal magement;

dummy = 1 indien bedrijfseconomie;

dummy $=1$ indien fiscale economie

dummy = 1 indien kwantitatieve economie, sociologische economie, verkeer- en vervoerseconomie, economie Europese integratie, staatkundige economie, vrij doctoraaltracé economie, economie niet nader aangeduid of onbekend.

Aantal maanden tussen afstudeermaand en enquête maand.

Totaal aantal maanden werkzoekend tussen afstudeermaand en enquêtemaand.

dummy $=0$ indien werkend in provincie Groningen Friesland, Drenthe, Overijssel, Gelderland of Flevoland (referentiecategorie);

dummy $=1$ indien werkend in provincie Utrecht, NoordHolland, Zuid-Holland of Zeeland

dummy $=1$ indien werkend in provincie Noord-Brabant of Limburg;

dummy = 1 indien werkend buiten Nederland.

dummy $=1$ indien respondent werkt in een profitorganisatie.

dummy = 1 indien respondent werkt in een organisatie met tenminste 100 personeelsleden.

dummy = 1 indien respondent meer dan 32 uur per week in dezelfde betaalde baan werkt. 
Vaste aanstelling

Baan in eigen domein

Baan op WO-nivo

Werkenvaring vereist

Leidinggevende baan dummy $=1$ indien respondent een vaste aanstelling heeft (incl. proeftijd bij vaste baan)

dummy = 1 indien voor de baan (door de werkgever) de zelf gevolgde opleidingsrichting of een daaraan verwante richting werd vereist.

dummy = 1 indien voor de baan (door de werkgever) een opleiding op academisch niveau werd vereist.

dummy = 1 indien voor de baan werkervaring (door de werkgever) werd vereist.

dummy $=1$ indien leiding aan andere medewerkers wordt gegeven. 